\title{
Bioavailability and Safety of Lipid Fraction from Different Taxa of Microalgae in Female C57BL/6 Mice
}

\author{
Alexander Lykov ${ }^{1,2,3, * \mathbb{D}}$, Ivan Uvarov ${ }^{4} \mathbb{D}$, Ruslan Gevorgiz ${ }^{5(\mathbb{D})}$, Svetlana Zheleznova ${ }^{5}$ (D), Maria \\ Surovtseva $^{1,2 \mathbb{D}}$, Irina Kim ${ }^{1,2} \mathbb{D}$, Natalia Bondarenko ${ }^{1,2} \mathbb{( D}$, Olga Poveshchenko $1,2 \mathbb{D}$
}

1 Research Institute of Clinical and Experimental Lymphology-Branch of the Institute of Cytology and Genetics Siberian Branch of the Russian Academy of Sciences, Novosibirsk, Russia; aplykov2@mail.ru (A.L.); mfelde@ngs.ru (M.S.); kii5@yandex.ru (I.K.); bond802888@yandex.ru (N.B.); poveschenkoov@yandex.ru (O.P.); Meshalkin National Medical

2 Research Center, Ministry of Health of the Russian Federation, Novosibirsk, Russia

3 Federal State Budgetary Institution "Novosibirsk Tuberculosis Research Institute", Ministry of Health of the Russian Federation/ Novosibirsk, Russia

4 State Budgetary Institution of the Novosibirsk Region "Department of Veterinary Medicine of the City Novosibirsk", Novosibirsk, Russia; 79139206791@mail.ru (I.U.);

5 A.O. Kovalevsky Institute of Biology of the South Seas Russian Academy of Sciences, Sevastopol, Russia; r.gevorgiz@yandex.ru (R.G.); zheleznovasveta@yandex.ru (S.Z.);

* Corresponding author e-mail address: aplykov2@mail.ru (A.L.);

Scopus Author ID: 7005078523

Received: 4.09.2021; Revised: 14.10.2021; Accepted: 18.10.2021; Published: 20.11.2021

Abstract: Microalgae exhibit antioxidant, anti-inflammatory effects. In this study, we analyzed the toxicity of lipid fraction of different taxa of microalgae in female C57BL/6 mice. The number of red blood cells, white blood cells and subsets, hemoglobin, number, and functional activities of immature and mature immunocytes, biochemical parameters in blood serum, and kidney and liver extract were investigated. It is shown that the lipid fraction of microalgae had no acute toxic effect on body weight, glucose blood levels, and hemopoiesis in mice. Some changes in the number of immature and mature lymphocytes, proliferative potential, Ig levels, cytokine production were determined. In vivo lipid fraction of microalgae caused changes in cytokine, protein, lipid, purine, aminotransferases, and sex hormone level in mice. Obtained data indicate that lipid fraction dietary administration in female C57BL/6 mice does not have a toxic effect on the animal.

Keywords: lipid fraction of microalgae; Chlorella vulgaris; Coelastrella sp.; Spirulina platensis; Cylindrotheca closterium; Porphyridium purpureum; hematopoiesis; immature and mature lymphocytes; proliferation; cytokine; protein and lipid status; aminotransferase activit; sex hormone.

(C) 2021 by the authors. This article is an open-access article distributed under the terms and conditions of the Creative Commons Attribution (CC BY) license (https://creativecommons.org/licenses/by/4.0/).

\section{Introduction}

Microalgae and cyanobacteria are rich sources of valuable compounds, including important bioactive and biotechnologically relevant chemicals [1, 2]. Microalgae and cyanobacteria contain proteins, fats (fatty acids, mono - and polyunsaturated acids, trans fatty acids), carbohydrates, and vitamins, including groups B, K, E, various carotenoids, and pigments [3, 4]. For example, the inclusion of a dietary supplement based on Chlorella vulgaris in mice with cyclophosphane-induced immunosuppression contributed to the restoration of immunity. Namely, it increases the proliferative potential of lymphocytes, activates phagocytosis of macrophages, stimulates the cytotoxic activity of natural killer cells and enhances the production of interleukin (IL) -2, 12, tumor necrosis factor-alpha and gamma interferon [5]. Arthrospira (Spirulina) platensis is used as a dietary supplement for humans and 
animals, capable of stimulating the antiviral activity of the immune system and increasing the efficiency of growth by influencing the morphology of the intestine [5]. For example, including in diet of $A$. platensis in chickens increases body weight, the titer of antibodies against the ND vaccine, the length of the villi, and the number of goblet cells in the intestine [5]. The aqueous extract of Chlorella vulgaris and Arthrospira (Spirulina) platensis oral administration in mice with glutamate-induced ovarian dysfunction improves oocyte maturation quality and speed [1]. Dietary administration of Chlorella vulgaris, Nannochloropsis oceanica, and Phaeodactylum tricornutum in mice no have a significant effect on organ weight and length of the intestine [6]. We have previously shown that fucoxanthin isolated from Cylindrotheca closterium (Ehrenb.) Reimann et Lewin and immobilized on an organosilicon carrier increased the survival and proliferation of splenocytes and thymocytes in vitro, and in vivo did not cause damage to enterocytes [4]. Microalgae are a source of exopolysaccharides that can stimulate the proliferation of immunocytes [7]. The presence of antioxidants in microalgae helps to reduce the production of proinflammatory cytokines in the skin, which can be used to develop drugs for the treatment of skin pathology [8]. In a rat model of age-related liver steatosis induced by D-galactose, the introduction of Dunaliella salina microalgae biomass, polar fraction, carotenoid fraction, or isolated zeaxanthin geneucosylate per os improved liver functions, indirectly through the regulation of redox status, markers of inflammation, and apoptosis [9]. It was shown that fucoxanthin isolated from Phaeodactylum tricornutum suppresses the activation of NF-kB and NLRP3 signaling pathways in bone marrow immunocytes; astrocytes involved in the synthesis and secretion of proinflammatory cytokines IL- $1 \beta$, IL- 6 , and TNF- $\alpha$ initiated by a combination of lipopolysaccharide and ATP, activating the suppression of the expression of caspase-1 component of the NLRP3 inflammasome [10].

The purpose of this study was a comparative study of the effect of lipid fraction extract of microalgae of different taxa on hematopoiesis, immune system, and biochemical parameters in female C57BL/6 mice.

\section{Materials and Methods}

The study included green microalgae (Chlorella vulgaris Beijerink and Coelastrella sp.), cyanobacteria (Arthrospira (Spirulina) platensis (Nordstedt) Gomont), diatoms (Cylindrotheca closterium (Ehrenb.) Reimann et Lewin), and red (Porphyridium purpureum (Bory) Drew et Ross). The cultures of microalgae were obtained from the collection of A.O. Kovalevsky Institute of Biology of the South Seas Russian Academy of Sciences (Sevastopol). For this purpose, the cultures were grown in flasks on luminostat at $5 \mathrm{klx}$, using a cumulative cultivation method. Nutrient media were used in the work, the composition of which is given below. As the density of the culture increased, a fresh nutrient medium was added, so they were supplied until the volume reached $1 \mathrm{~L}$ of each type of microalgae. After adaptation, the entire volume of each of the cultures was used as an inoculum for growing in 2.5 and 10 L flat-panel photobioreactors (Figure 1a). To build up $10 \mathrm{~L}$ of microalgae suspension, a cumulative cultivation method with active cross-linking by bubbling with air under artificial lighting (15 $\mathrm{klx}$ ) with fluorescent lamps was also used. After reaching the stationary growth phase, the entire volume $(10 \mathrm{~L})$ was used as an inoculum to cultivate photobioreactors under artificial light.

Intensive cultivation of microalgae on a large scale was carried out in open type

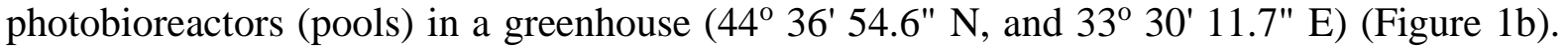
The enclosed volume of the suspension in each photobioreactor was 254 L (Fugere 1c and 1d). 
This volume was maintained throughout the experiment by adding tap water to the level of $254 \mathrm{~L}$. The depth of the suspension was $10 \mathrm{~cm}$. The illuminated surface is $2.54 \mathrm{~m}^{2}$. The suspension of microalgae in photobioreactors was mixed by means of a mechanical stirrer, the rotation speed of which was unchanged throughout the day and was $20 \mathrm{rpm}$. To maintain the optimal temperature of the suspension, a thermal stabilization system was used, while during the entire cultivation time, the deviation from the optimal temperature was no more than $3{ }^{\circ} \mathrm{C}$.

(a)

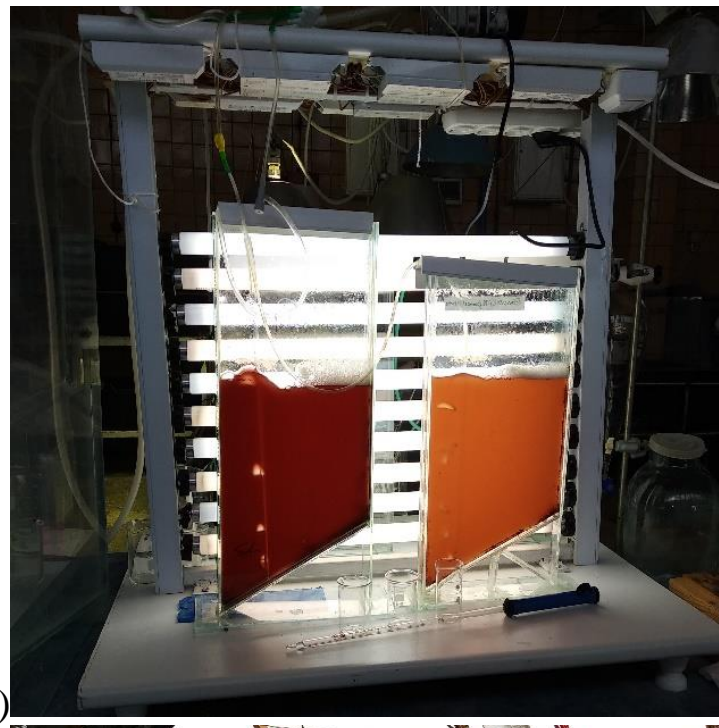

(c)

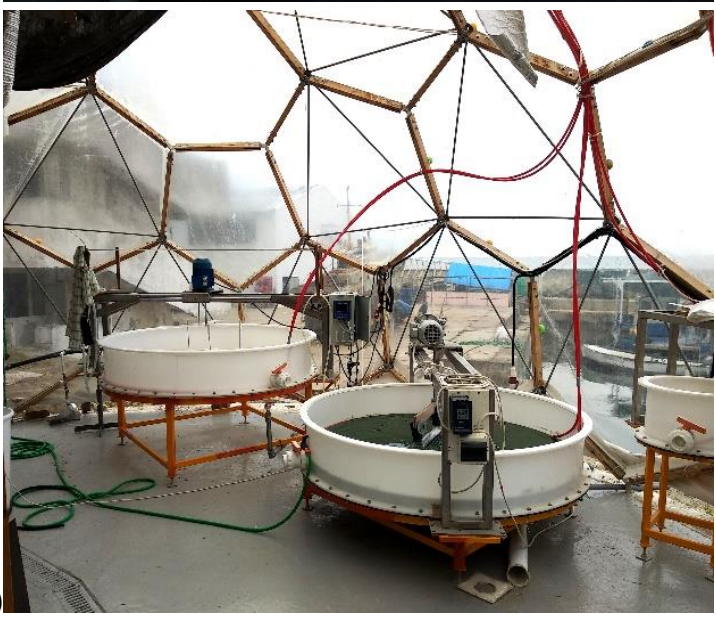

(b)

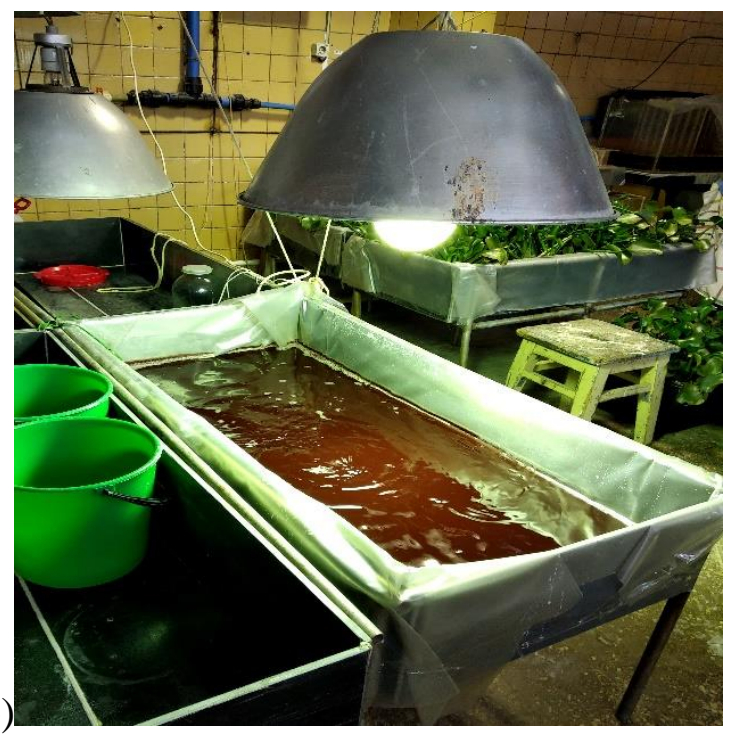

(d)

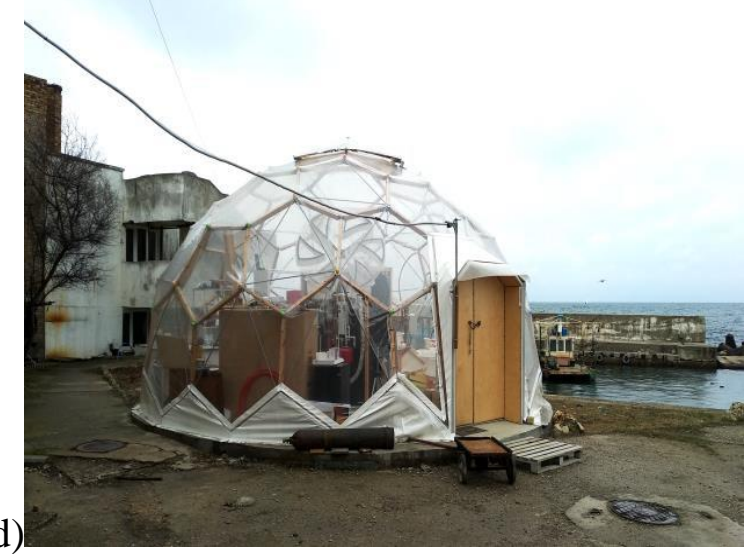

Figure 1. Photobioreactor for microalgae growth. (a) a Porphyridium purpureum in $2 \mathrm{~L}$ flat-parallel photobioreactor; (b) a 70 L photobioreactors; (c) Arthrospira (Spirulina platensis) in industrial $254 \mathrm{~L}$ photobioreactors; (d) a general view of the industrial photobioreactor (dome).

Two methods measured the change in the culture density in the photobioreactor: measuring the optical density of the suspension in a $0.5 \mathrm{~cm}$ cuvette at a wavelength of $750 \mathrm{~nm}$ and weighing the raw residue (algae biomass) on analytical scales after centrifugation of the suspension in polypropylene tubes at $1600 \mathrm{~g}$ for 15 minutes.

Green microalgae and cyanobacteria were grown in the summer. Red and diatom algae were grown in the autumn-winter period. At the first stage of intensive cultivation of microalgae in industrial photobioreactors, the cultures were adapted to natural lighting conditions for two days. For this purpose, the inoculate obtained in the laboratory was diluted with the fresh nutrient medium in a ratio of 1:3 and placed in an industrial cultivator. To increase the depth of the suspension and reduce the illuminated surface during adaptation, one edge of the cultivator was raised by $5 \mathrm{~cm}$ so that the entire suspension flowed to the opposite edge of the cultivator. To exclude the death of an unadapted culture from high illumination, 
the suspension was shaded with a cloth so that the illumination of the working surface was 10$15 \mathrm{klx}$. After adaptation, the cultures were grown in an intensive mode without shading the working surface of the photobioreactor. As the density of the culture increased, a nutrient medium was added. The suspension obtained in this way was used as an inoculum for intensive cultivation in an industrial photobioreactor under natural light.

For the cultivation of freshwater species Chlorella vulgaris (C. vulgaris), Coelastrella sp., Arthrospira (Spirulina) platensis (A. platensis), standard nutrient media Tamiya and Zarruk prepared on filtered tap water were used. The Zarruk medium consists of $16.8 \mathrm{~g} / 1 \mathrm{NaHCO}_{3}, 0.5$ $\mathrm{g} / \mathrm{L} \mathrm{K}_{2} \mathrm{HPO}_{4}, 2.5 \mathrm{~g} / \mathrm{L} \mathrm{NaNO}_{3}, 1.0 \mathrm{~g} / \mathrm{L} \mathrm{K}_{2} \mathrm{SO}_{4}, 1.0 \mathrm{~g} / \mathrm{L} \mathrm{NaCl}, 0.08 \mathrm{~g} / \mathrm{L} \mathrm{Na} \mathrm{EDTA}_{2}, 0.01 \mathrm{~g} / \mathrm{L}$ $\mathrm{FeSO}_{4} \times 7 \mathrm{H}_{2} \mathrm{O}, 0.04 \mathrm{~g} / \mathrm{L} \mathrm{CaCl} 2 \times 2 \mathrm{H}_{2} \mathrm{O}, 0.2 \mathrm{~g} / \mathrm{L} \mathrm{MgSO} \mathrm{M}_{4} \times 7 \mathrm{H}_{2} \mathrm{O}$ and $1 \mathrm{~mL} / \mathrm{L}$ a mixture of trace elements $\left(2.86 \mathrm{~g} / \mathrm{L} \mathrm{H}{ }_{3} \mathrm{BO}_{3}, 1.81 \mathrm{~g} / \mathrm{L} \mathrm{MnCl}_{2} \times 4 \mathrm{H}_{2} \mathrm{O}, 0.222 \mathrm{~g} / \mathrm{L} \mathrm{ZnSO} 4 \times 7 \mathrm{H}_{2} \mathrm{O}, 0.079 \mathrm{~g} / \mathrm{L}\right.$ $\mathrm{CuSO}_{4} \times 5 \mathrm{H}_{2} \mathrm{O}, 0.15 \mathrm{~g} / \mathrm{L} \mathrm{MoO}_{3}, 0.02296 \mathrm{~g} / \mathrm{L} \mathrm{NH}_{4} \mathrm{VO}_{3}, 0.04398 \mathrm{~g} / \mathrm{L} \mathrm{Co}\left(\mathrm{NO}_{3}\right)_{2} \times 6 \mathrm{H}_{2} \mathrm{O}, 0.096$ $\mathrm{g} / \mathrm{L} \mathrm{K} \mathrm{Cr}_{2}\left(\mathrm{SO}_{4}\right)_{4} \times 24 \mathrm{H}_{2} \mathrm{O}, 0.04785 \mathrm{~g} / \mathrm{L} \mathrm{NiSO}_{4} \times 7 \mathrm{H} 2 \mathrm{O}, 0.01794 \mathrm{~g} / \mathrm{L} \mathrm{Na}_{2} \mathrm{WO}_{4} \times 2 \mathrm{H}_{2} \mathrm{O}$ and $\left.0.04 \mathrm{~g} / \mathrm{L} \mathrm{Ti}_{2}\left(\mathrm{SO}_{4}\right)_{3}\right)$. The Tamiya nutrient medium included $5.0 \mathrm{~g} / \mathrm{L} \mathrm{KNO}_{3}, 2.25 \mathrm{~g} / \mathrm{L} \mathrm{MgSO}_{4} \times$ $7 \mathrm{H}_{2} \mathrm{O}, 1.25 \mathrm{~g} / \mathrm{L} \mathrm{KH}_{2} \mathrm{PO}_{4}, 0.003 \mathrm{~g} / \mathrm{L} \mathrm{FeSO}_{4} \times 7 \mathrm{H}_{2} \mathrm{O}, 0.0037 \mathrm{~g} / \mathrm{L}$ EDTA and $1 \mathrm{~mL} / \mathrm{L}$ mixtures of trace elements $\left(2.86 \mathrm{~g} / \mathrm{L} \mathrm{H}_{3} \mathrm{BO}_{3}, 1.81 \mathrm{~g} / \mathrm{L} \mathrm{MnCl}_{2} \times 4 \mathrm{H}_{2} \mathrm{O}, 0.222 \mathrm{~g} / \mathrm{L} \mathrm{ZnSO}_{4} \times 7 \mathrm{H}_{2} \mathrm{O}, 0.01764\right.$ $\mathrm{g} / \mathrm{L} \mathrm{MoO}_{3}$ and $\left.0.02296 \mathrm{~g} / \mathrm{L} \mathrm{NH}_{4} \mathrm{VO}_{3}\right)$.

For the cultivation of marine species of microalgae, Cylindrotheca closterium $(C$. closterium) and Porphyridium purpureum (P. purpureum), RS and Trenkensha nutrient media prepared on sterile Black Sea water were used. The composition of the RS nutrient medium included $0.75 \mathrm{~g} / \mathrm{L} \mathrm{NaNO}_{3}, 0.0641 \mathrm{~g} / \mathrm{L} \mathrm{NaH}_{2} \mathrm{PO}_{4} \times 2 \mathrm{H}_{2} \mathrm{O}, 0.386 \mathrm{~g} / \mathrm{L} \mathrm{Na}_{2} \mathrm{SiO}_{3} \times 9 \mathrm{H}_{2} 0,0.0872$ $\mathrm{g} / \mathrm{L} \mathrm{Na} 2$ EDTA, $0.05 \mathrm{~g} / \mathrm{L} \mathrm{FeSO}_{4} \times 7 \mathrm{H}_{2} \mathrm{O}, 0.0002 \mathrm{~g} / \mathrm{L} \mathrm{CuSO}_{4} \times 5 \mathrm{H}_{2} \mathrm{O}, 0.00044 \mathrm{~g} / \mathrm{L} \mathrm{ZnSO}_{4} \times$ $7 \mathrm{H}_{2} \mathrm{O}, 0.0002 \mathrm{~g} / \mathrm{L} \mathrm{CoCl} 2 \times 6 \mathrm{H}_{2} \mathrm{O}, 0.00036 \mathrm{~g} / \mathrm{L} \mathrm{MnCl}_{2} \times 4 \mathrm{H}_{2} \mathrm{O}$ and $0.00012 \mathrm{~g} / \mathrm{L} \mathrm{NaMoO} \times$ $\mathrm{H}_{2} \mathrm{O}$. The composition of the Trenkenschu nutrient medium included $1.8 \mathrm{~g} / \mathrm{L} \mathrm{NaNO}, 0.3 \mathrm{~g} / \mathrm{L}$ $\mathrm{NaH}_{2} \mathrm{PO}_{4}$ x $2 \mathrm{H}_{2} \mathrm{O}, 0.37 \mathrm{~g} / \mathrm{L} \mathrm{Na} 2 \mathrm{EDTA}, 0.042 \mathrm{~g} / \mathrm{L} \mathrm{FeC}_{6} \mathrm{H}_{5} \mathrm{O}_{7} \times 3 \mathrm{H}_{2} \mathrm{O}, 0.008 \mathrm{~g} / \mathrm{L} \mathrm{MnCl}_{2} \times 4 \mathrm{H}_{2} \mathrm{O}$, $0.00625 \mathrm{~g} / \mathrm{L} \mathrm{Co}\left(\mathrm{NO}_{3}\right)_{2} \times 6 \mathrm{H}_{2} \mathrm{O}, 0.00183 \mathrm{~g} / \mathrm{L}\left(\mathrm{NH}_{4}\right) 6 \mathrm{Mo}_{7} \mathrm{O}_{24} \times 4 \mathrm{H}_{2} \mathrm{O}, 0.00238 \mathrm{~g} / \mathrm{L} \mathrm{K}_{2} \mathrm{Cr}_{2} \mathrm{SO}_{4} \times$ $24 \mathrm{H}_{2} \mathrm{O}$ and $0.00058 \mathrm{~g} / \mathrm{L} \mathrm{TiO}_{2}$.

After reaching the stationary growth phase, microalgae suspension from an industrial photobioreactor was centrifuged at $1600 \mathrm{~g}$ for 15 minutes. The liquid was removed, and the raw algae mass was washed with fresh water to remove the remnants of salts and exometabolites. The Spirulina suspension was filtered through tissue with pores of 45 microns. Then they were also washed with fresh water.

To obtain a dry mass of algae, the raw biomass was applied in a thin layer (3-5 $\mathrm{mm}$ ) on polyethylene laid on a flat surface and dried in a warm air current $\left(38^{\circ} \mathrm{C}\right)$ to a residual humidity $9-10 \%$. The dry mass of algae was stored in a tightly sealed container at $-18^{\circ} \mathrm{C}$.

\subsection{Microalgae oil extract preparation.}

Lipid fraction from microalgae of different taxa ( $5 \mathrm{~g}$ per $100 \mathrm{ml}$ of sunflower oil) was obtained by passive diffusion of biologically active substances in a thermostat (TS-80, Russia) for 72 hours at $37^{\circ} \mathrm{C}$; then, they were impregnated with standard granulated food for rodents (300 g).

\subsection{Animals.}

All experiments were performed with the prior approval of the Ethics Committee of Research Institute of Clinical and Experimental Lymphology-Branch of the Institute of 
Cytology and Genetics RAS, and were conducted in accordance with the principles and guidelines of the Declaration of Helsinki. Female C57BL/6 mice (25-30 g) were obtained from a vivarium at the Research Institute of Neuroscience and Medicine (Novosibirsk, Russia) and maintained under standard conditions (temperature $20-25^{\circ} \mathrm{C}, 12$ hours light/dark cycle), and received water and food ad libitum. The experimental groups were formed in accordance with the studied microalgae extracts: Chlorella vulgaris Beijerink (Chlorella), Coelastrella sp.(Coelastrella), Arthrospira (Spirulina) platensis (Nordstedt) Gomont) (Spirulina), Cylindrotheca closterium (Ehrenb.) Reimann et Lewin (Cylindrotheca), Porphyridium purpureum (Bory), Drew et Ross (Prophyridium), and control (standard granulated food for rodents soaked with pure sunflower oil). The sample size in the experimental groups was 5 individuals and 6 individuals in the control group. The animals received food treated with lipid fraction of microalgae or only sunflower oil for 12 days. Bodyweight was measured on days 0 , 7 , and 12. The animals were removed from the experiment by dislocation of the cervical spine; peripheral blood was taken to prepare blood serum, the spleen, thymus, kidneys, and liver were extracted.

\subsection{Hematopoiesis and hemaglobin.}

The number of red blood cells (RBC), white blood cells (WBC), the population of WBC in peripheral blood on days 0,7 , and 12 taken after cutting the tip of the tail was determined by a standard count in the Goryaev chamber. The leukocyte formula was calculated on a microscope according to the generally accepted method after staining a blood smear with a May-Grunwald fixative and subsequent staining according to Romanovsky-Giemsa (Abris+, Russia). Hemoglobin levels were determined spectrophotometrically using the HemoglobinNovo kit (Vector-BEST, Russia).

\subsection{Immunocytes.}

The spleen and thymus tissue were crushed into small pieces with eye scissors, then broken using syringes and needles from large to small diameter, filtered through strainers with a pore diameter of 80 microns.

\subsection{MTT test.}

Proliferative potential of splenocytes and thymocytes $\left(10^{6} / \mathrm{mL}\right)$ in medium RPMI 1640 (Biolot, Russia) with the addition of $10 \%$ fetal calf serum (Hyclone, USA), 2 mM L-glutamine (Merck, USA), $5 \mathrm{mM}$ Hepes buffer (Sigma, USA) and $80 \mathrm{mcg} / \mathrm{mL}$ gentamicin sulfate (Dalkhimpharm, Russia) in 24-well flat-bottomed culture plates (TRP, Switzerland) was evaluated by incubation at 72 hours at $37^{\circ} \mathrm{C}$ and an atmosphere of $5 \% \mathrm{CO}_{2} / 95 \%$ air in the presence of 0 and $10 \mu \mathrm{g} / \mathrm{mL}$ of Concanavalin A (Con A; Sigma, USA). Then, 4 hours before the end of the experiment, the cells were precipitated by centrifugation at $1500 \mathrm{rpm}$ for 5 minutes, the supernatant was removed and collected in aliquots and stored at $-70^{\circ} \mathrm{C}, 100 \mu \mathrm{L}$ of medium RPMI 1640 without supplements and $10 \mu \mathrm{L}$ of 3-(4,5-dimethylthiazole-2-yl)-2,5diphenyl-2 N-tetrazolium bromide (MTT, Merck, USA) were added and incubated for 4 hours at $37^{\circ} \mathrm{C}$ and an atmosphere of $5 \% \mathrm{CO}_{2} / 95 \%$ air. Then $100 \mu \mathrm{L}$ of dimethyl sulfoxide (DMSO; Merck, USA) was added to the wells to destroy the cell membrane; the optical density of the reaction product in the well was evaluated by spectrophotometry at a wavelength of $492 \mathrm{~nm}$ (StatFax 2100, USA). 


\subsection{Extract of kidney and liver preparation.}

The kidneys and liver were filled with $1 \mathrm{~mL}$ of DMSO and destroyed in a homogenizer; then the resulting mass was centrifuged 10 minutes at $3000 \mathrm{rpm}$, supernatants were collected in aliquots and stored at $-70^{\circ} \mathrm{C}$.

\subsection{ELISA}

The levels of IL-1 $\beta$, IL-10, TNF $\alpha$ were determined in blood serum, conditioned media from lymphocytes, and extracts of kidney and liver tissues using commercial kits Interleukin1 beta-ELISA-BEST, Interleukin-10-ELISA-BEST, alpha TNF-ELISA-BEST (Vector, Russia), according to the manufacturer's instructions. The immunoglobulins (Ig) levels of class G, M, A were studied in blood serum spectrophotometrically using the Immunoscreen-G,M,AELISA-BEST kit (Vector-BEST, Russia) according to the manufacturer's instructions.

2.9. Proteins, lipoproteins, cholesterol, triglycerides, creatine, urea, uric acid, transferases, blood glucose, and sex hormone detection.

The levels of albumin, protein, low-density lipoprotein cholesterol (LDL-C), highdensity lipoproteins-cholesterol (HDL-C), total cholesterol TC), triglycerol (TG), creatinine, urea, uric acid, alanine and aspartate aminotransferase (ALT, AST respectively), and sex hormones (progesterone, testosterone) were determined in biological media using commercial Vector-BEST kits (Russia). Blood glucose was determined using Gluco Calea (wellionvet, MED TRUST, Austria).

\subsection{Nitric oxide determination.}

Nitric oxide (NO) production by lymphocytes in blood serum and extracts of kidney and liver were measured using Griess reagent for nitrite determination (Merck, USA). The levels of NO were calculated using a sodium nitrite standard curve.

\subsection{Statistical analysis.}

Data were analyzed by Statistica 10.0 for Windows. In this study, the normality of the distribution was determined by the w-Shapiro-Wilkes criterion, in tables, the obtained data were presented as mean \pm standard deviation (SD), the data were analyzed by one-way analysis of variance (ANOVA) with a Bonferroni correction (Bonferroni post hoc test) to analyze differences between groups. If p-values were less than 0.05 , it was considered statistically significant.

\section{Results and discussion}

\subsection{Acute toxicity of lipid fraction of microalgae.}

Acute toxicity of the lipid fraction of microalgae of different taxa was studied by survival, body weight changes, and the effect on hematopoiesis parameters.

We have estimated that the lipid fraction of Cylindrotheca, and Porphyridium after 7 and 12 days of dietary administration possess an increase in body weight compared to other microalgae but did not significantly differ from the control group of mice (Figure 2a). There was no significant effect of the lipid fraction of microalgae on blood glucose levels, except for 
an increase on day 7 in the group of Spirulina, and Porphyridium compared to the control (Figure 2b).

Also, we have no observed significant effect of the lipid fraction of microalgae on the number of RBC and hemoglobin in mice compared with the control, except for a decrease in hemoglobin on day 12 in Porphyridium group of mice (Table 1).

While the lipid fraction of microalgae on day 12 decreases the number of WBC in Chlorella, and Cylindrotheca groups compared with other experimental and control groups ( $\mathrm{p}$ $<0.05)$. The decrease in leukocytes in the peripheral blood of mice is due to a change in the population composition, mainly granulocytes, and lymphocytes (Table 1). Data indicated no acute toxicity in mice that received lipid fractions of different taxa of microalgae.

(a)

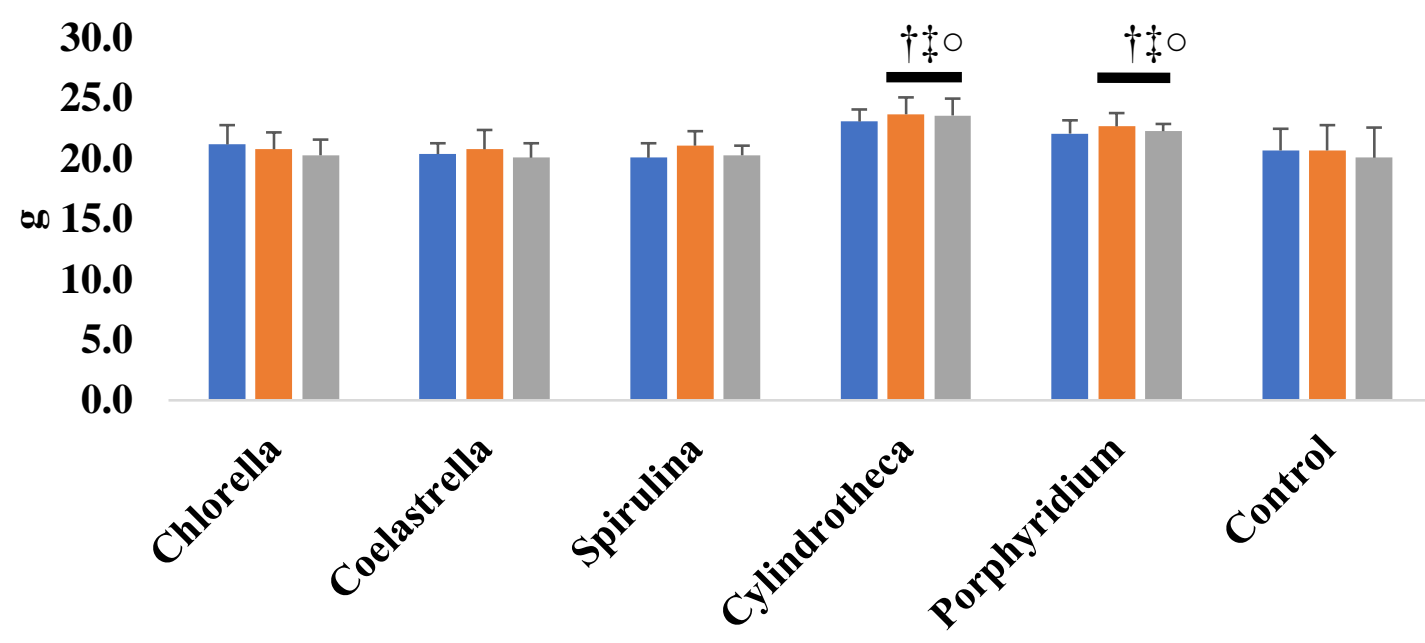

- Day 0 Day 7 Day 12

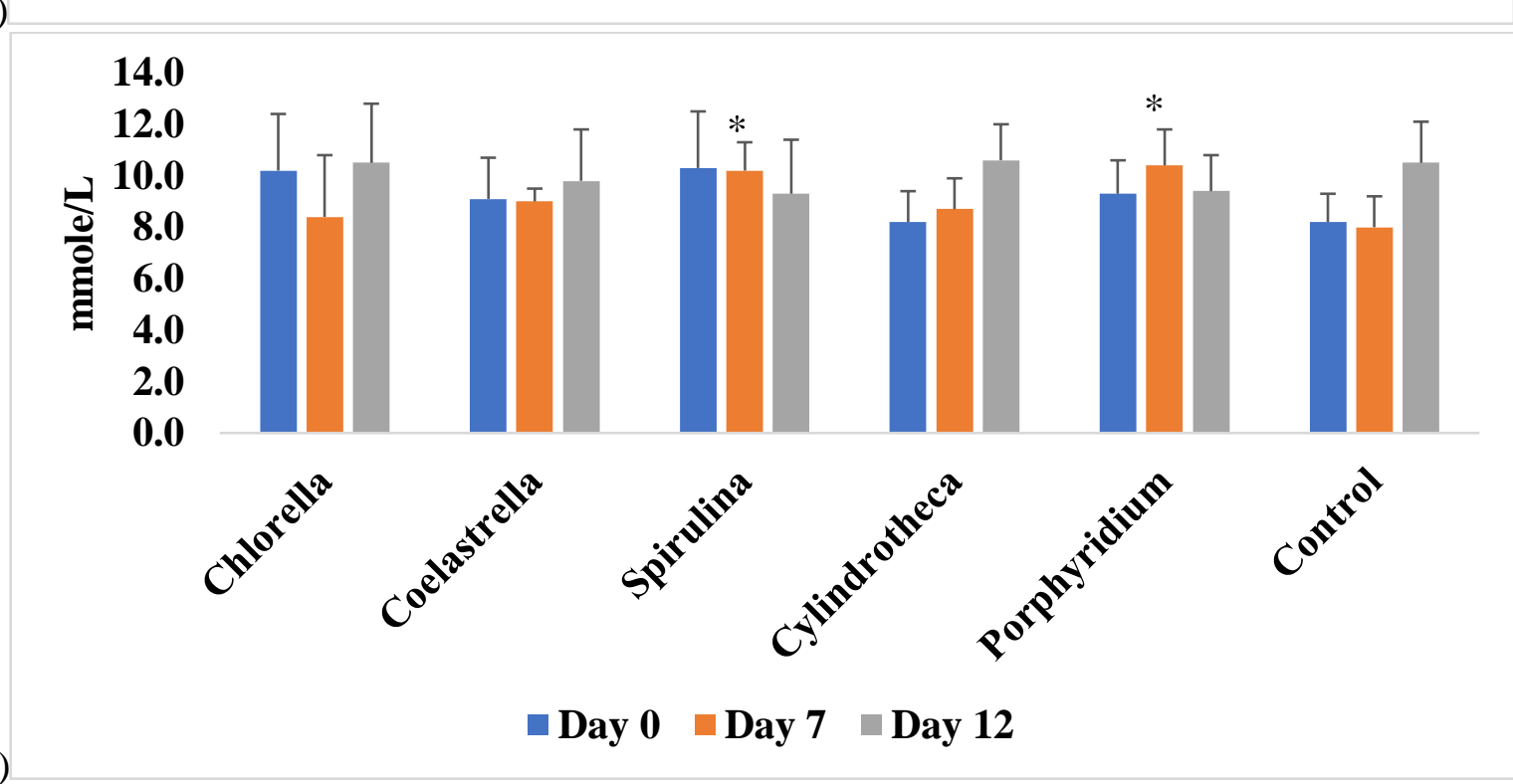

Figure 2. Effect of the lipid fraction of microalgae on (a) body weight and (b) glucose level in the blood in female C57BL/6 mice (M $\pm \mathrm{SD}$ ). Note: $p<0.05$ †with Chlorella, $\$$ with Coelastrella, owith Spirulina

Cylindrotheca, $\diamond$ with Porphyridium, * with control.

Table 1. Effect of lipid fraction of microalgae on hematopoiesis $(\mathrm{M} \pm \mathrm{SD})$.

\begin{tabular}{l|l|l|l|l|l|l} 
Parameters & Chlorella & Coelastrella & Spirulina & Cylindrotheca & Porphyridium & Control \\
\hline \multicolumn{7}{c}{ Day 0 } \\
\hline $\mathrm{RBC}, 10^{12} / \mathrm{L}$ & $4.9 \pm 0.2$ & $4.9 \pm 0.2$ & $4.9 \pm 0.1$ & $4.9 \pm 0.1$ & $4.9 \pm 0.1$ & $4.9 \pm 0.1$ \\
\hline $\mathrm{Hg}, \mathrm{g} / \mathrm{L}$ & $158.6 \pm 3.8$ & $160.4 \pm 4.2$ & $159.2 \pm 4.3$ & $147.4 \pm 23.4$ & $158.8 \pm 2.8$ & $155.33 \pm 5.8$ \\
\hline WBC, $10^{9} / \mathrm{L}$ & $8.8 \pm 0.9$ & $9.5 \pm 1.8$ & $9.5 \pm 2.0$ & $9.0 \pm 0.8$ & $9.3 \pm 1.6$ & $9.8 \pm 1.8$ \\
https://biointerfaceresearch.com/
\end{tabular}




\begin{tabular}{|c|c|c|c|c|c|c|}
\hline Parameters & Chlorella & Coelastrella & Spirulina & Cylindrotheca & Porphyridium & Control \\
\hline \multicolumn{7}{|c|}{ Day 0} \\
\hline Gr, $\%$ & $27.0 \pm 1.0 \dagger+\circ \diamond \diamond$ & $37.0 \pm 1.0$ & $24.0 \pm 1.0$ & $36.0 \pm 1.0$ & $42.0 \pm 1.0$ & $21.0 \pm 1.0$ \\
\hline $\mathrm{M}, \%$ & $8.0 \pm 1.0$ & $8.0 \pm 1.0$ & $12.0 \pm 1.0$ & $4.0 \pm 1.0$ & $8.0 \pm 1.0$ & $10.0 \pm 1.0$ \\
\hline Lym, \% & $65.0 \pm 1.0 \dagger$ & $56.0 \pm 1.0$ & $64.0 \pm 1.0$ & $60.0 \pm 1.0$ & $50.0 \pm 1.0$ & $69.0 \pm 1.0$ \\
\hline \multicolumn{7}{|c|}{ Day 7} \\
\hline $\mathrm{RBC}, 10^{12} / \mathrm{L}$ & $4.9 \pm 0.1$ & $5.0 \pm 0.1$ & $4.8 \pm 0.3$ & $4.6 \pm 0.2$ & $4.7 \pm 0.3$ & $4.7 \pm 0.3$ \\
\hline $\mathrm{Hg}, \mathrm{g} / \mathrm{L}$ & $152 \pm 10$ & $154.7 \pm 4.1$ & $155.4 \pm 3.6$ & $157.7 \pm 6.4$ & $152.5 \pm 3.2$ & $161.0 \pm 6.4$ \\
\hline WBC, $10^{9} / \mathrm{L}$ & $8.0 \pm 2.1$ & $9.6 \pm 1.7$ & $9.7 \pm 1.6$ & $8.2 \pm 2.5$ & $7.7 \pm 1.6$ & $9.8 \pm 1.6$ \\
\hline Gr, $\%$ & $26.5 \pm 0.9$ & $36,0 \pm 1.5$ & $23.5 \pm 1.0$ & $38.0 \pm 1.5$ & $41.5 \pm 1.0$ & $24.0 \pm 1.0$ \\
\hline $\mathrm{M}, \%$ & $7.5 \pm 0.9$ & $7.5 \pm 1.0$ & $11.5 \pm 1.0$ & $4.0 \pm 1.0$ & $7.8 \pm 1.0$ & $9.5 \pm 1.0$ \\
\hline Lym, \% & $66.0 \pm 1.0$ & $56.5 \pm 1.0$ & $65 \pm 1.0$ & $58.0 \pm 1.0$ & $50.7 \pm 1.0$ & $66.5 \pm 1.0$ \\
\hline \multicolumn{7}{|c|}{ Day 12} \\
\hline $\mathrm{RBC}, 10^{12} / \mathrm{L}$ & $4.4 \pm 0.2$ & $4.6 \pm 0.2$ & $4.7 \pm 0.2$ & $4.6 \pm 0.1$ & $4.7 \pm 0.3$ & $4.7 \pm 0.2$ \\
\hline $\mathrm{Hg}, \mathrm{g} / \mathrm{L}$ & $162.9 \pm 6.0 \diamond$ & $162.0 \pm 4.1 \diamond$ & $160.8 \pm 4.7 \diamond$ & $160.7 \pm 2.2 \diamond$ & $152.5 \pm 3.2 *$ & $163.9 \pm 5.9$ \\
\hline WBC, $10^{9} / \mathrm{L}$ & $6.4 \pm 1.1+t$ & $8.5 \pm 1.0 \circ$ & $7.7 \pm 0.4 \circ$ & $6.4 \pm 0.7 *$ & $7.7 \pm 1.6$ & $7.8 \pm 0.4$ \\
\hline $\mathrm{Gr}, \%$ & $26.2 \pm 1.1+\div \circ \diamond$ & $35.6 \pm 1.7 \ddagger \circ \diamond *$ & $23.0 \pm 1.2 \diamond 0$ & $36.8 \pm 5.4$ & $41.0 \pm 1.4^{*}$ & $26.5 \pm 5.6$ \\
\hline $\mathrm{M}, \%$ & $7.2 \pm 0.8 \pm 0 *$ & $7.4 \pm 0.9 \$ \circ *$ & $11.2 \pm 1.1 \circ \diamond$ & $4.2 \pm 0.4$ & $7.6 \pm 0.9 *$ & $9.5 \pm 0.8$ \\
\hline Lym, \% & $66.6 \pm 1.5 \dagger \circ \diamond$ & $57.2 \pm 1.9 \ddagger \circ \diamond$ & $65.8 \pm 1.9 \circ \diamond$ & $61.0 \pm 1.4 \diamond^{*}$ & $51.4 \pm 2.2 *$ & $64.2 \pm 5.5$ \\
\hline
\end{tabular}

\subsection{Effect of the lipid fraction of microalgae on the immune system.}

Effect of the lipid fraction of different taxa of microalgae was analyzed based on the number of immature and mature lymphocytes (thymocytes, and splenocytes respectively), proliferative activity of lymphocytes, and immunoglobulin (Ig) level in blood serum of mice.

For the most part, after 12 days of the administration, microalgae possess a decrease in the number of splenocytes compared to the control, except for the Spirulina group, in which an increase in the number of splenocytes was noted (Table 2).

In addition, there was a decrease in basal proliferative activity in the experimental groups of mice compared to the control group, especially in the Chlorella group. In response to the mitogenic stimulus, a significant decrease in the proliferative response was revealed in Chlorella, Coelastrella, and Spirulina groups compared to the control and other experimental groups of mice $(\mathrm{p}<0.05)$.

In Chlorella, Spirulina, and Porphyridium groups on Day 12 observed a significantly increased number of thymocytes compared with other experimental groups and control $(\mathrm{p}<$ $0.05)$.

The lipid fraction of different taxa of microalgae had no significant effect on basal and mitogen-stimulated proliferative potential of thymocytes except for Cylindrotheca and Porphyridium groups compared with control $(\mathrm{p}<0.05)$.

We estimated that the lipid fraction of Coelastrella significantly increased blood serum level of IgG compared with other experimental and control groups (Figure 3). The lipid fraction of different taxa of microalgae did not significantly affect IgM and IgA levels in blood serum in mice $(\mathrm{p}>0.05)$.

Data indicated that the lipid fraction of microalgae affected mature and immature lymphocytes' quantity and quality. 
Table 2. Effect of the lipid fraction of microalgae on thymocytes and splenocytes number and proliferation $(\mathrm{M} \pm \mathrm{SD})$.

\begin{tabular}{|c|c|c|c|c|c|c|}
\hline \multirow[t]{3}{*}{ Parameters } & \multicolumn{3}{|c|}{ Splenocytes } & \multicolumn{3}{|c|}{ Thymocytes } \\
\hline & \multirow{2}{*}{$\begin{array}{l}\text { Number, } \\
10^{6} / \mathrm{mL}\end{array}$} & \multicolumn{2}{|c|}{ Proliferation, OD } & \multirow{2}{*}{$\begin{array}{l}\text { Number, } \\
10^{6} / \mathrm{mL}\end{array}$} & \multicolumn{2}{|c|}{ Proliferation, OD } \\
\hline & & basal & ConA & & basal & ConA \\
\hline Chlorella & $85.7 \pm 3.4 \dagger \circ \diamond_{*}$ & $0.5 \pm 0.01 \dagger+\circ \diamond_{*}$ & $0.5 \pm 0.01+\neq \circ \diamond$ & $60.7 \pm 0.9 \dagger \div 0 *$ & $0.5 \pm 0.01$ & $0.5 \pm 0.01 \circ \diamond$ \\
\hline Coelastrella & $86.3 \pm 1.2 \ddagger \circ \diamond_{*}$ & $0.6 \pm 0.01 \circ \diamond *$ & $0.6 \pm 0.01$ & $43.1 \pm 0.9 \pm 0$ & $0.5 \pm 0.01 \circ \diamond$ & $0.5 \pm 0.01 \circ \diamond$ \\
\hline Spirulina & $110.9 \pm 1.2 \diamond^{*}$ & $0.6 \pm 0.01 \circ \diamond^{*}$ & $0.6 \pm 0.01 \circ \diamond_{*}$ & $55.9 \pm 0.9 \circ \diamond^{*}$ & $0.5 \pm 0.01 \circ \diamond$ & $0.5 \pm 0.01 \circ \diamond$ \\
\hline Cylindrotheca & $96.3 \pm 1.4^{*}$ & $0.7 \pm 0.01 *$ & $0.8 \pm 0.01$ & $43.0 \pm 0.9 \diamond$ & $0.6 \pm 0.01 *$ & $0.6 \pm 0.01 *$ \\
\hline Porphyridium & $98.8 \pm 1.8^{*}$ & $0.7 \pm 0.01 *$ & $0.8 \pm 0.01$ & $61.7 \pm 1.2 *$ & $0.6 \pm 0.01 *$ & $0.6 \pm 0.01 *$ \\
\hline Control & $122.8 \pm 2.0$ & $0.8 \pm 0.01$ & $0.8 \pm 0.01$ & $44.0 \pm 1.3$ & $0.5 \pm 0.01$ & $0.5 \pm 0.01$ \\
\hline
\end{tabular}

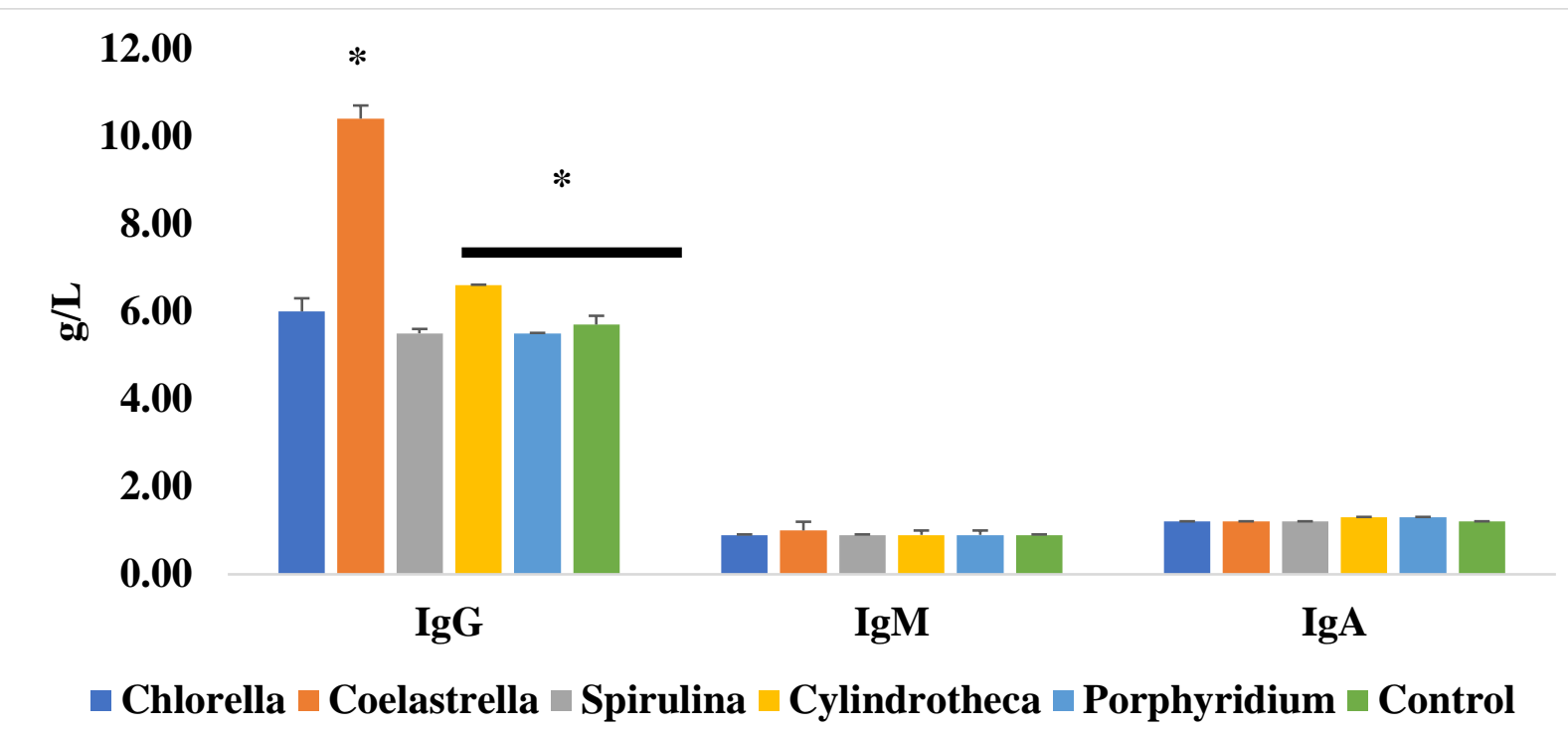

Figure 3. Effect of lipid fraction on $\mathrm{IgG}, \mathrm{M}$, A serum levels in female C57BL/6 mice (M+SD). Note: $p<0.05$ *with Coelastrella.

\subsection{Effect of the lipid fraction of microalgae on cytokine and nitric oxide levels.}

In blood serum and tissues extract (kidney and liver) using ELISA was determined proinflammatory (IL-1 $\beta$, and IL-1 $\beta$ ), and anti-inflammatory (IL-10), and NO level in mice on Day 12.

Table 3. Effect of the lipid fraction of microalgae on cytokine and NO level in blood serum and the extract of kidney and liver in female C57BL/6 mice $(\mathrm{M} \pm \mathrm{SD})$.

\begin{tabular}{|c|c|c|c|c|}
\hline \\
\hline Parameters & IL-1 $\beta, \mathrm{pg} / \mathrm{mL}$ & TNF $\alpha, p g / m L$ & IL-10, pg/mL & NO, micromole/mL \\
\hline \multicolumn{5}{|c|}{ In blood serum } \\
\hline Chlorella & $86.9 \pm 1.4 \dagger *$ & $149.1 \pm 4.7 \dagger^{*}$ & $21.5 \pm 0.2 \ddagger \circ \diamond$ & $55.1 \pm 5.3+\circ \diamond$ \\
\hline Coelastrella & $80.6 \pm 3.0 \dagger$ & $201.3 \pm 25.4 \dagger \circ \diamond^{*}$ & $21.6 \pm 0.4 \circ \diamond$ & $50.8 \pm 0.7 \ddagger \circ \diamond *$ \\
\hline Spirulina & $120.7 \pm 48.6$ & $173.6 \pm 30.5$ & $20.9 \pm 0.3$ & $47.3 \pm 0.2 \circ \diamond *$ \\
\hline Cylindrotheca & $95.8 \pm 20.8$ & $153.5 \pm 6.7$ & $20.4 \pm 0.2$ & $48.3 \pm 0.4 \diamond *$ \\
\hline Porphyridium & $83.0 \pm 7.2$ & $146.8 \pm 2.8^{*}$ & $20.7 \pm 0.1$ & $96.2 \pm 2.4 *$ \\
\hline Control & $80.3 \pm 2.8$ & $160.2 \pm 2.3$ & $20.9 \pm 0.5$ & $52.4 \pm 0.1$ \\
\hline \multicolumn{5}{|c|}{ In kidney extract } \\
\hline Chlorella & $78.9 \pm 3.9 \ddagger$ & $151.9 \pm 12.8 \dagger$ & $20.6 \pm 0.5 \ddagger \circ$ & $45.1 \pm 0.7 \ddagger \circ \diamond_{*}$ \\
\hline Coelastrella & $78.4 \pm 0.7 \ddagger \circ *$ & $135.9 \pm 2.5 \ddagger \circ \diamond *$ & $20.4 \pm 0.2 \ddagger 0$ & $45.9 \pm 4.4$ \\
\hline Spirulina & $94.8 \pm 13.9 \diamond$ & $149.4 \pm 3.2$ & $21.6 \pm 0.6$ & $49.3 \pm 0.2 *$ \\
\hline Cylindrotheca & $93.1 \pm 13.8 \diamond$ & $147.5 \pm 8.4$ & $21.7 \pm 0.6^{*}$ & $50.1 \pm 0.8^{*}$ \\
\hline Porphyridium & $77.7 \pm 1.5^{*}$ & $146.7 \pm 15.6$ & $20.8 \pm 0.5$ & $49.9 \pm 0.6^{*}$ \\
\hline Control & $92.7 \pm 9.8$ & $148.2 \pm 10.5$ & $20.6 \pm 0.4$ & $47.7 \pm 0.4$ \\
\hline https://biointer & arch.com/ & & & 6853 \\
\hline
\end{tabular}




\begin{tabular}{|c|c|c|c|c|}
\hline Parameters & IL-1 $\beta, p g / m L$ & TNF $\alpha, p g / m L$ & IL-10, pg/mL & NO, micromole/mL \\
\hline \multicolumn{5}{|c|}{ In liver extract } \\
\hline Chlorella & $80.2 \pm 4.2 \circ \diamond$ & $143.5 \pm 3.2 \dagger \diamond *$ & $20.6 \pm 0.4 \diamond *$ & $54.6 \pm 0.4 \dagger \circ \diamond$ \\
\hline Coelastrella & $84.7 \pm 9.0$ & $169.7 \pm 17.9$ & $21.0 \pm 0.7$ & $53.0 \pm 1.0 \ddagger \circ \diamond$ \\
\hline Spirulina & $75.7 \pm 3.5 \diamond$ & $136.0 \pm 5.8 *$ & $20.4 \pm 0.4 \diamond^{*}$ & $49.2 \pm 0.4 \diamond^{*}$ \\
\hline Cylindrotheca & $73.3 \pm 1.6 \circ *$ & $164.7 \pm 18.9 *$ & $20.3 \pm 0.7 \diamond *$ & $48.2 \pm 1.8 \diamond^{2} *$ \\
\hline Porphyridium & $83.7 \pm 1.0$ & $171.1 \pm 21.0$ & $21.6 \pm 0.3$ & $111.3 \pm 17.4^{*}$ \\
\hline Control & $80.7 \pm 3.0$ & $152.4 \pm 4.5$ & $21.5 \pm 0.2$ & $53.9 \pm 0.6$ \\
\hline
\end{tabular}

We have indicated an increased level of IL-1 $\beta$ in the blood serum of the Chlorella group of mice compared with Control (Table 3). While another lipid fraction of microalgae no had a significant effect on IL-1 $\beta$ level in blood serum compared with control. In Chlorella, and Porphyridium groups of mice, we observed decreased level of $\mathrm{TNF} \alpha$, and in the Coelastrella group of mice, an increased level of TNF $\alpha$ compared with the control $(\mathrm{p}<0.05)$. There was no significant effect of the lipid fraction of different taxa of microalgae on IL-10 level in blood serum compared with the control group ( $\mathrm{p}>0.05)$. While IL-10 level in Chlorella and Coelastrella groups was significantly higher than in other experimental groups $(\mathrm{p}<0.05)$. In Coelastrella, Spirulina, and Cylindrotheca groups, there was determined decreased level of NO, while in Porphyridium group, an increased level of NO compared with control ( $\mathrm{p}<0.05)$.

In the kidney, tissues extracted from the Coelastrella and Porphyridium group we determined decreased of IL-1 $\beta$ level compared with control ( $\mathrm{p}<0.05)$. Only in the Coelastrella group of mice, TNF $\alpha$ level in kidney extract was significantly decreased compared with control $(\mathrm{p}<0.05)$. At the same time, the IL-10 level in kidney extract of the Cylindrotheca group was higher than control (Table 3). The NO level in kidney extract from an experimental group of mice was significantly higher, while in the Chlorella group a significantly lower compared with the control, while there was no significant difference of $\mathrm{NO}$ level in the Coelastrella group with control.

In liver tissues extracts in the Cylindrotheca group, there was estimated a lower level of IL-1 $\beta$ compared with control $(\mathrm{p}<0.05)$, while in another experimental group, we observed no significant effect of the lipid fraction of microalgae on IL-1 $\beta$ level compared with control (Table 3). In Chlorella and Spirulina groups in liver extract, a significantly decreased level of TNF $\alpha$ was determined, while in the Cylindrotheca group, an increased level of TNF $\alpha$ compared with control ( $\mathrm{p}<0.05)$. Chlorella, Spirulina, and Cylindrotheca groups decreased IL-10 level in liver extract compared with control ( $\mathrm{p}<0.05)$. The NO level in liver extracts of the Spirulina and Cylindrotheca groups was lower than in control, while in the Porphyridium group a significantly higher $(\mathrm{p}<0.05)$.

Table 4. Effect of the lipid fraction of microalgae on cytokine and NO production by lymphocytes $(\mathrm{M} \pm \mathrm{SD})$.

\begin{tabular}{|c|c|c|c|c|}
\hline Parameters & IL-1 $\beta, \mathrm{pg} / \mathrm{mL}$ & TNFo, pg/mL & IL-10, pg/mL & NO, micromole/Ml \\
\hline \multicolumn{5}{|c|}{ Splenocytes basal level production } \\
\hline Chlorella & $75.2 \pm 0.9 \circ$ & $147.5 \pm 2.5 \circ \diamond$ & $21.5 \pm 1.1$ & $40.7 \pm 0.6$ \\
\hline Coelastrella & $78.7 \pm 4.2$ & $146.9 \pm 4.7 \circ \diamond$ & $20.9 \pm 0.2$ & $40.0 \pm 0.2$ \\
\hline Spirulina & $79.4 \pm 5.8$ & $142.8 \pm 3.8$ & $21.3 \pm 0.8$ & $40.0 \pm 0.4$ \\
\hline Cylindrotheca & $82.5 \pm 4.0$ & $138.6 \pm 1.4$ & $20.0 \pm 0.5$ & $40.4 \pm 0.4$ \\
\hline Porphyridium & $101.2 \pm 24.7$ & $137.5 \pm 2.2$ & $22.3 \pm 1.7 *$ & $40.4 \pm 0.4$ \\
\hline Control & $77.8 \pm 3.6$ & $143.6 \pm 10.2$ & $20.3 \pm 0.2$ & $42.8 \pm 3.1$ \\
\hline \multicolumn{5}{|c|}{ Splenocytes ConA level production } \\
\hline Chlorella & $74.1 \pm 2.4 \uparrow \circ *$ & $151.2 \pm 0.5$ & $20.3 \pm 0.5^{*}$ & $39.5 \pm 0.5$ \\
\hline Coelastrella & $79.2 \pm 0.6 \div \circ \diamond$ & $149.8 \pm 9.3$ & $20.6 \pm 0.2 t^{*}$ & $39.8 \pm 0.1$ \\
\hline Spirulina & $71.7 \pm 1.2 \circ *$ & $146.1 \pm 3.2$ & $20.0 \pm 0.3^{*}$ & $39.1 \pm 0.3$ \\
\hline
\end{tabular}




\begin{tabular}{|c|c|c|c|c|}
\hline Parameters & IL-1ß, pg/mL & TNF $\alpha, p g / m L$ & IL-10, pg/mL & NO, micromole/Ml \\
\hline Cylindrotheca & $102.2 \pm 1.4 \diamond^{*}$ & $172.0 \pm 30.6$ & $20.2 \pm 0.2 *$ & $39.2 \pm 0.7$ \\
\hline Porphyridium & $73.2 \pm 0.8 *$ & $144.6 \pm 10.7$ & $20.3 \pm 0.4 *$ & $39.3 \pm 0.1$ \\
\hline Control & $82.5 \pm 4.0$ & $151.9 \pm 3.9$ & $21.3 \pm 0.1$ & $40.0 \pm 1.3$ \\
\hline \multicolumn{5}{|c|}{ Thymocytes basal level production } \\
\hline Chlorella & $88.5 \pm 2.4 \dagger \diamond^{*}$ & $152.0 \pm 10.6$ & $21.7 \pm 0.3 \dagger *$ & $40.7 \pm 0.3$ \\
\hline Coelastrella & $84.6 \pm 0.4 *$ & $154.4 \pm 5.4 \div \diamond^{*} *$ & $21.0 \pm 0.1 \div \circ *$ & $41.2 \pm 0.4$ \\
\hline Spirulina & $92.5 \pm 15.2$ & $136.9 \pm 3.3$ & $21.6 \pm 0.3^{*}$ & $39.9 \pm 0.5$ \\
\hline Cylindrotheca & $83.0 \pm 2.9 *$ & $161.7 \pm 14.2$ & $21.4 \pm 0.9 *$ & $40.9 \pm 0.1$ \\
\hline Porphyridium & $83.5 \pm 0.3 *$ & $142.8 \pm 5.3$ & $21.7 \pm 0.2 *$ & $42.4 \pm 2.7$ \\
\hline Control & $77.5 \pm 1.9$ & $141.8 \pm 1.5$ & $20.3 \pm 0.2$ & $43.6 \pm 3.3$ \\
\hline \multicolumn{5}{|c|}{ Thymocytes ConA level production } \\
\hline Chlorella & $84.2 \pm 2.9 \dagger \circ \diamond_{*}$ & $145.9 \pm 1.7$ & $22.2 \pm 0.6 \dagger 0$ & $40.4 \pm 0.3$ \\
\hline Coelastrella & $79.0 \pm 1.5 \circ$ & $145.1 \pm 1.5$ & $20.9 \pm 0.6^{*}$ & $39.8 \pm 0.5$ \\
\hline Spirulina & $90.4 \pm 21$ & $143.5 \pm 6.7$ & $24.2 \pm 3.5$ & $39.9 \pm 0.6 \circ \diamond$ \\
\hline Cylindrotheca & $74.7 \pm 1.6$ & $169.2 \pm 14.5$ & $20.4 \pm 0.5 \diamond^{*} *$ & $39.0 \pm 0.1 *$ \\
\hline Porphyridium & $79.7 \pm 1.9$ & $144.3 \pm 3.1$ & $21.5 \pm 0.3$ & $39.8 \pm 0.7$ \\
\hline Control & $76.4 \pm 1.9$ & $150.2 \pm 7.8$ & $21.8 \pm 0.2$ & $40.2 \pm 0.6$ \\
\hline
\end{tabular}

Note: ConA, Concanavalin A-stimulated production. $p<0.05$ † with Coelastrella, \$with Spirulina, owith Cylindrotheca, ৩with Porphyridium, *with control.

The effect of the lipid fraction of different taxa of microalgae on lymphocytes' cytokine production was determined using ELISA.

The conditioned medium from splenocytes only in the Porphyridium group determined increased IL-10 basal production compared with control (Table 4). At the same time, others observed a significant difference in the IL-1 $\beta, \mathrm{TNF} \alpha$, IL-10, and NO basal production by splenocytes compared with control $(\mathrm{p}>0.05)$. While in conditioned medium from mitogenstimulated splenocytes, there was a decreased level of IL-1 $\beta$ production in Chlorella, Spirulina, and Porphyridium groups. In the Cylindrotheca group, we observed an increased level of IL$1 \beta$ production compared with the control $(\mathrm{p}<0.05)$. Non had estimated a significant difference in TNF $\alpha$ and NO production by ConA stimulated splenocytes with control ( $p>0.05$ ). In contrast, the production of IL-10 by stimulated splenocytes in experimental groups of mice was significantly lower than in control $(\mathrm{p}<0.05)$.

In conditioned medium from thymocytes, increased basal IL-1 $\beta$ production in experimental groups expect Spirulina group (Table 4). Only in the Coelastrella group, we observe increased basal production of $\mathrm{TNF} \alpha$, while other experimental groups had no significant difference from control. IL-10 basal production by thymocytes in all experimental groups was higher than in control $(\mathrm{p}<0.05)$. Non had observed difference in NO basal production by thymocytes compared with control $(\mathrm{p}>0.05)$. Only in the Chlorella group did we determine increased ConA-stimulated IL-1 $\beta$ production by thymocytes compared with control. Non had observed a significant difference in TNF $\alpha$ and NO production by mitogenstimulated thymocytes compared with control expect in the Cylindrotheca group. In conditioned medium from ConA-stimulated thymocytes in Coelastrella and Cylindrotheca, we determined a significant difference in IL-10 production compared with control $(\mathrm{p}<0.05)$.

Data indicated that lipid extract of different taxa of microalgae affected mice's cytokine basal or mitogen-stimulated production by immature and mature lymphocytes.

\subsection{The lipid fraction of microalgae affects protein, lipid, and purine metabolism.}

Using ELISA, we studied the effect of the lipid fraction of different taxa of microalgae on protein, lipid, and purine metabolism in mice. 
In the blood serum of mice, there was decreased albumin in Chlorella, Coelastrella, Spirulina, and Cylindrotheca, while it increased in the Porphyridium group compared with control (Table 5). The protein levels in blood serum were elevated in experimental groups compared with control ( $\mathrm{p}<0.05)$.

In kidney and liver tissues extracted from experimental groups, we determined a significantly higher protein level than control $(\mathrm{p}<0.05)$.

Table 5. Effect of the lipid fraction of microalgae at protein status in female C57BL/6 mice (M \pm SD).

\begin{tabular}{|c|c|c|c|c|c|}
\hline \multirow[t]{2}{*}{ Parameters } & \multicolumn{3}{|c|}{ Blood serum } & \multicolumn{2}{|c|}{$\operatorname{Protein}(2)$ in tissue extract, $\mathrm{g} / \mathrm{L}$} \\
\hline & Albumin, g/L & $\operatorname{Protein}(1), \mathrm{g} / \mathrm{L}$ & $\operatorname{Protein}(2), \mathrm{g} / \mathrm{L}$ & Kidney & Liver \\
\hline Chlorella & $32.2 \pm 0.2+\div \circ \diamond *$ & $67.6 \pm 0.1+\dagger \circ \diamond *$ & $0.5 \pm 0.01+\div \diamond^{*}$ & $0.52 \pm 0.01+\dagger \circ \diamond_{*}$ & $0.64 \pm 0.01+\div \circ \diamond_{*}^{*}$ \\
\hline Coelastrella & $37.3 \pm 0.03 \div \circ \diamond *$ & $64.1 \pm 0.1 \diamond^{*}$ & $0.52 \pm 0.01 \ddagger 0$ & $0.5 \pm 0.01 \ddagger \circ \diamond *$ & $0.69 \pm 0.01 \$ \circ *$ \\
\hline Spirulina & $33.9 \pm 0.1 \diamond *$ & $65.7 \pm 1.2 *$ & $0.54 \pm 0.01 \circ \diamond^{*}$ & $0.66 \pm 0.01 \diamond *$ & $0.58 \pm 0.01 \circ \diamond *$ \\
\hline Cylindrotheca & $33.9 \pm 0.1 \diamond *$ & $64.4 \pm 0.2 \diamond *$ & $0.49 \pm 0.01 \diamond *$ & $0.62 \pm 0.04 *$ & $0.5 \pm 0.01 \diamond^{*}$ \\
\hline Porphyridium & $48.7 \pm 0.1 *$ & $66.4 \pm 0.1 *$ & $0.74 \pm 0.07 *$ & $0.6 \pm 0.01 *$ & $0.7 \pm 0.07 *$ \\
\hline Control & $36.5 \pm 0.2$ & $62.3 \pm 0.07$ & $0.52 \pm 0.01$ & $0.5 \pm 0.01$ & $0.55 \pm 0.01$ \\
\hline
\end{tabular}

Note: Protein(1), a protein detected by interaction with copper ions; Protein(2), a protein detected by interaction with pyrogallol red. $p<0.05 \dagger$ with Coelastrella, $\$$ with Spirulina, owith Cylindrotheca, $\diamond$ with Porphyridium,

*with control.

In blood serum from experimental groups, an increased level of LDL-C and HDL-C was determined compared with control (Table 6). Chlorella, Coelastrella, and Spirulina groups decreased TC levels compared with control, while Cylindrotheca and Porphyridium groups had no estimated difference with control. TG increased in Coelastrella and Porphyridium groups compared with control $(\mathrm{p}<0.05)$.

Table 6. Effect of the lipid fraction of microalgae on lipid status in blood serum in female C57BL/6 mice

$(\mathrm{M} \pm \mathrm{SD})$.

\begin{tabular}{|c|c|c|c|c|}
\hline Parameters & LDL-C, mmole/L & HDL-C, mmole/L & TC, mmole/L & TG, mmole/L \\
\hline Chlorella & $1.8 \pm 0.01+\div \circ \diamond *$ & $3.4 \pm 0.1+\div \circ \diamond^{*}$ & $2.1 \pm 0.01 \circ \diamond_{*}$ & $1.6 \pm 0.01 \uparrow \diamond$ \\
\hline Coelastrella & $2.8 \pm 0.01 \div 0^{*}$ & $4.0 \pm 0.1 \circ \diamond$ & $2.1 \pm 0.01 \circ \diamond^{*}$ & $2.0 \pm 0.2 \circ \diamond *$ \\
\hline Spirulina & $2.3 \pm 0.01 \circ^{*}$ & $3.9 \pm 0.1 \circ \diamond *$ & $2.1 \pm 0.01 \circ \diamond *$ & $1.9 \pm 0.3$ \\
\hline Cylindrotheca & $1.9 \pm 0.01 \diamond^{*}$ & $4.1 \pm 0.1 \diamond$ & $2.2 \pm 0.01$ & $1.6 \pm 0.01 \diamond$ \\
\hline Porphyridium & $3.0 \pm 0.7$ & $4.5 \pm 0.01 *$ & $2.2 \pm 0.01$ & $1.9 \pm 0.01 *$ \\
\hline Control & $3.2 \pm 0.4$ & $4.2 \pm 0.1$ & $2.2 \pm 0.01$ & $1.6 \pm 0.01$ \\
\hline
\end{tabular}

Note: LDL-C, low-density lipoproteins-cholesterol; HDL-C, high-density lipoproteins-cholesterol; TC, total cholesterol; TG, triglycerol. $p<0.05$ †with Coelastrella, $\$$ with Spirulina, owith Cylindrotheca, $\diamond$ with Porphyridium, *with control.

Table 7. Effect of the lipid fraction of microalgae on markers of protein and purine metabolism in blood serum and kidney tissue extract in female C57BL/6 mice (M \pm SD).

\begin{tabular}{|c|c|c|c|}
\hline \\
\hline Parameters & Creatinine, mmole/L & Urea, mmole/L & Uric acid, mmole/L \\
\hline \multicolumn{4}{|c|}{ In blood serum } \\
\hline Chlorella & $24.6 \pm 0.01 \diamond$ & $7.6 \pm 0.1+1 \circ \diamond_{*}$ & $497.4 \pm 7.4 \div \diamond$ \\
\hline Coelastrella & $24.9 \pm 0.2 \diamond *$ & $7.8 \pm 0.01 \div 0^{*}$ & $472.8 \pm 7.4 \dagger \circ \diamond_{*}$ \\
\hline Spirulina & $33.2 \pm 7.7$ & $7.4 \pm 0.01 \circ \diamond *$ & $488.3 \pm 1.1 \circ \diamond_{*}$ \\
\hline Cylindrotheca & $33.2 \pm 6.5$ & $7.8 \pm 0.1 \diamond^{*}$ & $493.5 \pm 1.1 \diamond$ \\
\hline Porphyridium & $33.9 \pm 2.8 *$ & $10.0 \pm 0.01 *$ & $617.2 \pm 4.8 *$ \\
\hline Control & $26.4 \pm 0.7$ & $8.1 \pm 0.1$ & $494.8 \pm 2.1$ \\
\hline \multicolumn{4}{|c|}{ In kidney extract } \\
\hline Chlorella & $23.8 \pm 0.1 \dagger \circ \diamond *$ & $9.2 \pm 0.01+\dagger \circ \diamond^{*}$ & $479.9 \pm 2.6+1 \circ \diamond$ \\
\hline Coelastrella & $23.7 \pm 0.01 \dagger \circ \diamond_{*}$ & $6.7 \pm 0.01 \dagger \circ \diamond_{*}$ & $495.5 \pm 3.7 \ddagger \circ \diamond_{*}$ \\
\hline Spirulina & $24.2 \pm 0.1 \circ \diamond$ & $6.9 \pm 0.1 \circ \diamond *$ & $512.3 \pm 9.0 \circ \diamond_{*}$ \\
\hline Cylindrotheca & $30.1 \pm 2.8^{*}$ & $8.0 \pm 0.01 \diamond *$ & $463.7 \pm 1.1 \diamond^{*}$ \\
\hline
\end{tabular}




\begin{tabular}{l|l|l|l}
\hline Parameters & Creatinine, mmole/L & Urea, mmole/L & Uric acid, mmole/L \\
\hline Porphyridium & $24.7 \pm 0.1 \dagger+\diamond^{*}$ & $7.1 \pm 0.01$ & $484.5 \pm 7.4$ \\
\hline Control & $24.3 \pm 0.2$ & $7.2 \pm 0.1$ & $476.7 \pm 4.2$ \\
Note: $\mathrm{p}<0.05 \dagger$ †ith Coelastrella, + +with Spirulina, owith Cylindrotheca, $\diamond$ with Porphyridium, *with control.
\end{tabular}

The marker of protein metabolism (creatinine, urea) in blood serum indicated increased level in Coelastrella and Porphyridium groups of the creatinine compared with control, while we observed decreased level of the urea in Chlorella, Coelastrella, Spirulina, and Cylindrotheca groups and increased level in Porphyridium compared with control (Table 7). In kidney tissue extract, creatinine was decreased in Chlorella, Coelastrella, and increased in Cylindrotheca and Porphyridium compared with control $(\mathrm{p}<0.05)$. Urea level in the Coelastrella, Spirulina groups' kidney extract was decreased, and Chlorella and Cylindrotheca groups were increased compared with control $(\mathrm{p}<0.05)$.

The marker of purine metabolism in the Coelastrella and Spirulina groups' blood serum was decreased, while in the Porphyridium group were increased compared with control (Table 7). In addition, the kidney tissue extracts of the Coelastrella and Spirulina groups were increased, while in the Cylindrotheca group were decreased compared with the control ( $\mathrm{p}<$ $0.05)$.

Data indicated that the lipid fraction of microalgae had effects on protein, lipid, and purine metabolism in mice.

\subsection{Effect of the lipid fraction of microalgae on aminotransferase activity.}

In blood serum and liver tissue extract, we determined the activity of transferase using ELISA.

The lipid fraction of Porphyridium significantly increased ALT and AST activity in blood serum and liver tissue extract compared with other groups (Figure 4). Data have shown an adverse effect of Porphyridium on transferase activity in mice.

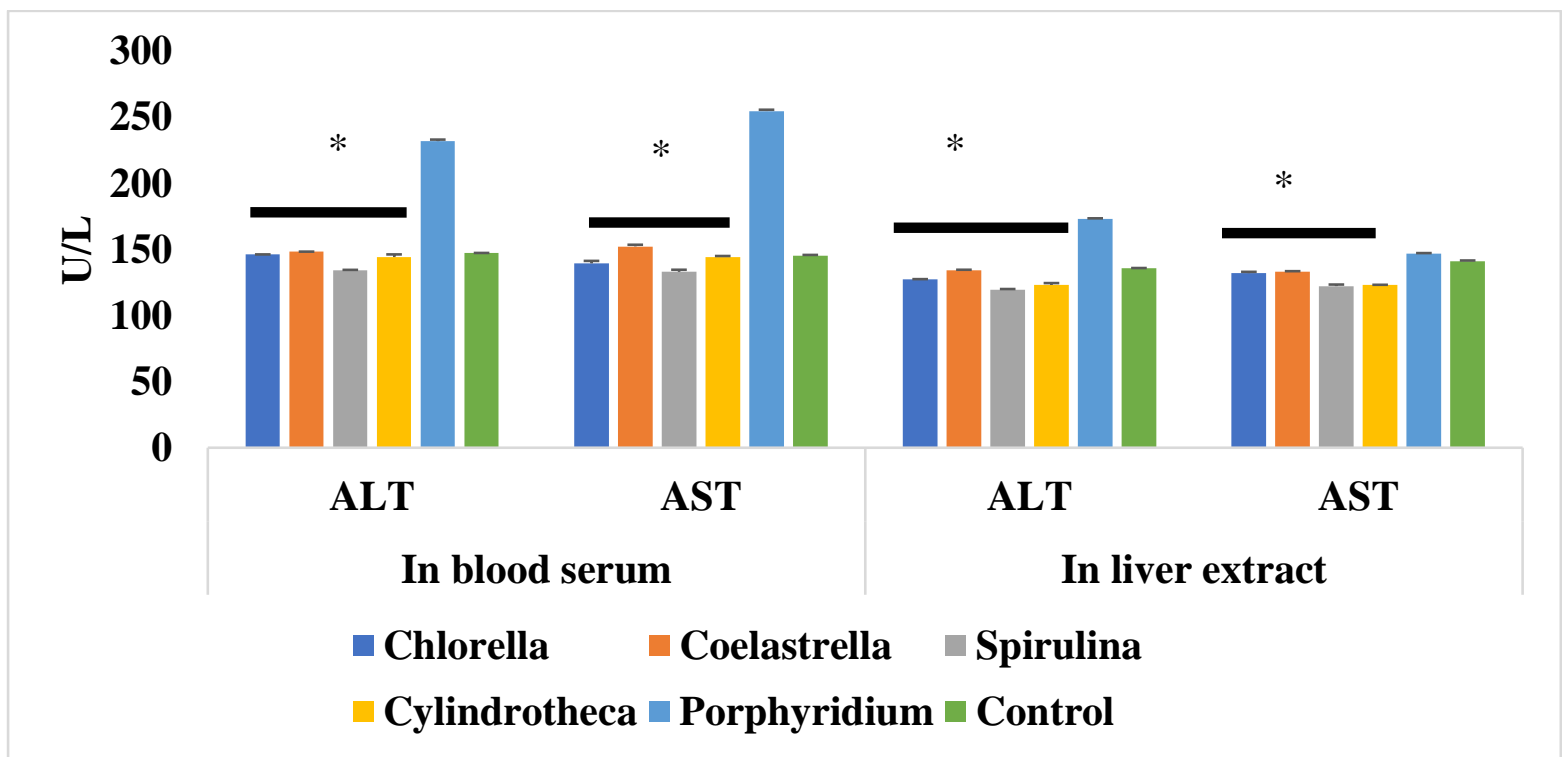

Figure 4. Effect of the lipid fraction of microalgae on alanine and aspartate aminotransferase level in blood serum and liver extract in female C57BL/6 mice. ALT, alanine aminotransferase; AST, aspartate aminotransferase. $\mathrm{p}<0.05 *$ with Porphyridium. 
3.6. Effect of the lipid fraction of microalgae on sex hormone.

Using ELISA in the blood serum of mice, we determined testosterone and progesterone levels.

The lipid fraction of Chlorella, Spirulina, and Cylindrotheca significantly increased testosterone in blood serum, while lipid fraction of Spirulina and Cylindrotheca significantly decreased progesterone level in blood serum of female C57BL/6 mice compared with other groups (Figure 5). Data indicate that microalgae may influence sex hormone balance in female mice.

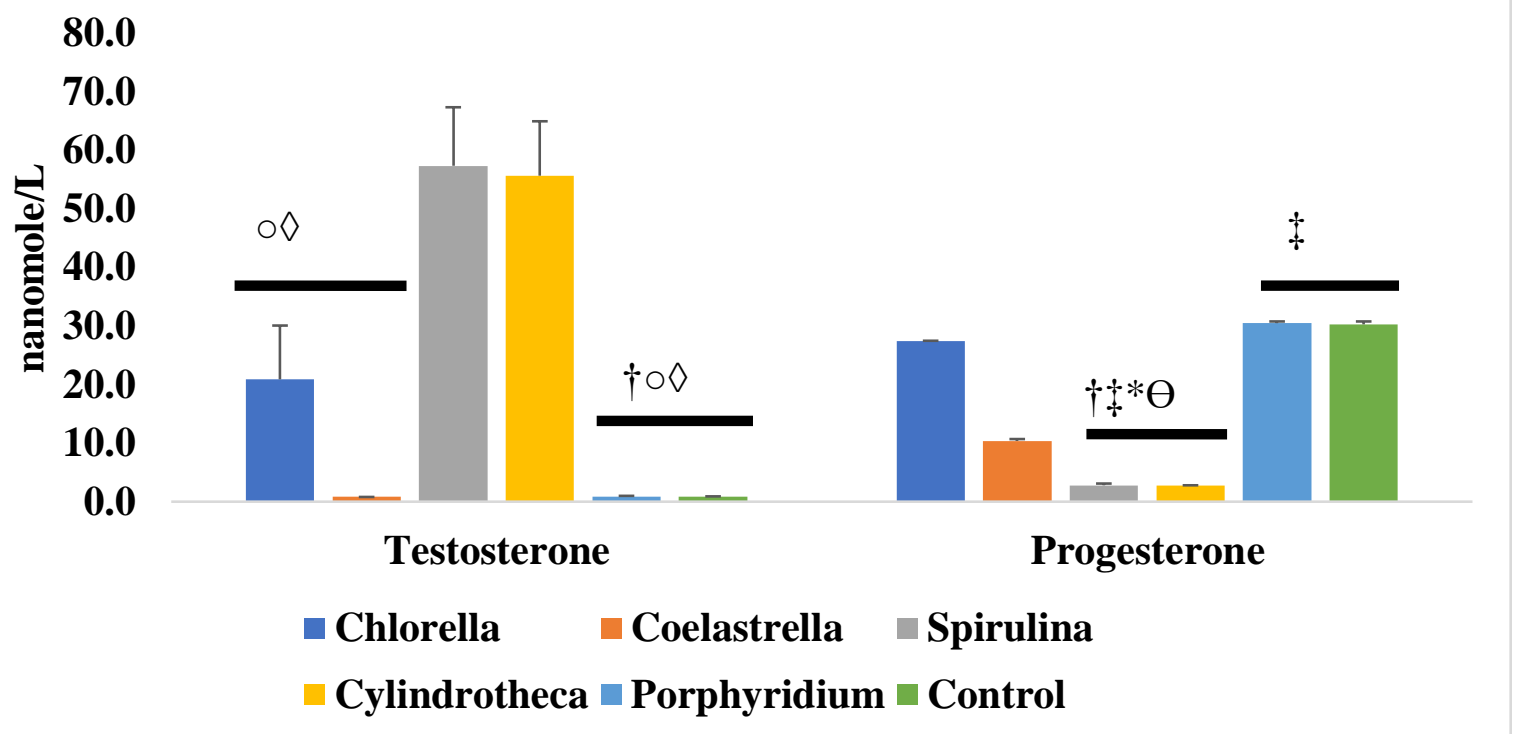

Figure 5. Effect of the lipid fraction of microalgae on sex hormone status in female C57BL/6 mice. $\mathrm{p}<0.05$ $\dagger$ †ith Chlorella, $\$$ with Coelastrella, owith Spirilina, $\diamond$ with Cylindrotheca, ${ }^{*}$ with Porphyridium, Owith control.

\subsection{Correlation.}

In Chlorella group estimated correlation between blood serum level of IL-1 $\beta$ and IL$1 \beta$ in liver tissues extract $(\mathrm{R}=-0.9, \mathrm{p}=0.037)$; between blood serum level of IL-10 and IL-10 level in kidney and liver tissues extract $(\mathrm{R}=-0.97, \mathrm{p}=0.0048)$ and between blood serum level of $\mathrm{TNF} \alpha$ and $\mathrm{TNF} \alpha$ level in kidney tissues extract $(\mathrm{R}=0.97, \mathrm{p}=0.0048)$.

In Coelastrella group found a correlation and between blood serum levels of TNF $\alpha$ and $\mathrm{TNF} \alpha$ levels in liver tissues extract $(\mathrm{R}=0.9, \mathrm{p}=0.037)$; between testosterone and progesterone level $(\mathrm{R}=-0.9, \mathrm{p}=0.037)$; between $\operatorname{IgG}$ and $\operatorname{IgA}(\mathrm{R}=-0.9, \mathrm{p}=0.037)$.

In Spirulina group estimated correlation between and between blood serum level of TNF $\alpha$ and TNF $\alpha$ level in liver tissues extract $(\mathrm{R}=-0.9, \mathrm{p}=0.037)$; between $\operatorname{IgM}$ and $\operatorname{IgA}(\mathrm{R}=-$ $0.9, \mathrm{p}=0.037)$.

In Cylindrotheca group found a correlation between $\mathrm{NO}$ level in blood serum and NO level in kidney and liver tissues extract $(\mathrm{R}=0.97, \mathrm{p}=0.0048$, and $\mathrm{R}=-0.97, \mathrm{p}=0.0048$ respectively); between IL- $1 \beta$ in blood serum and IL- $1 \beta$ level in kidney tissues extract $(\mathrm{R}=0.97$, $\mathrm{p}=0.0048)$; between IL-10 level in blood serum and IL-10 in kidney tissues extract $(\mathrm{R}=0.97$, $\mathrm{p}=0.0048)$; between $\mathrm{TNF} \alpha$ level in blood serum and TNF $\alpha$ level in liver tissues extract $(\mathrm{R}=0.9$, $\mathrm{p}=0.037)$.

In the Porphyridium group estimated correlation between IL-1 $\beta$ in blood serum and IL$1 \beta$ level in kidney tissues extract $(\mathrm{R}=0.9, \mathrm{p}=0.037)$; between $\mathrm{TNF} \alpha$ level in blood serum and $\mathrm{TNF} \alpha$ level in liver tissues extract $(\mathrm{R}=0.97, \mathrm{p}=0.014)$; between testosterone and progesterone $(\mathrm{R}=-0.94, \mathrm{p}=0.013)$. 
In the control group between IL-1 $\beta$ in blood serum and IL-1 $\beta$ level in kidney and liver tissues extract $(\mathrm{R}=0.97, \mathrm{p}=0.0013$, and $\mathrm{R}=-0.98, \mathrm{p}=0.0003$ respectively); between IL-10 level in blood serum and IL-10 level in kidney tissues extract $(\mathrm{R}=-0.92, \mathrm{p}=0.008)$; between TNF $\alpha$ level in blood serum and TNF $\alpha$ level in liver tissues extract $(\mathrm{R}=-0.88, \mathrm{p}=0.019)$; between testosterone and progesterone $(\mathrm{R}=0.92, \mathrm{p}=0.007)$.

Data reflect correlations between serum level of cytokines and their level in kidney and liver tissues and the presence of a balance between sex hormones.

\section{Discussion}

This study showed that lipid fraction of different taxa of microalgae had no acute toxicity after dietary administration during the 12-th day in mice based on body weight, glucose blood level, and hematological signs, such as RBC hemoglobin, WBC, and WBC subsets. In addition, we found that the lipid fraction of microalgae in common decreased the number of mature lymphocytes (splenocytes), increased the number of immature lymphocytes (thymocytes), and influenced Ig levels in blood serum. The lipid fraction of microalgae had an effect on cytokine levels in blood serum, tissues extract (kidney and liver), and basal and mitogen-stimulated production by lymphocytes. Moreover, we showed that the lipid fraction of microalgae influenced protein, lipid, and purine metabolism. In addition, we found that the lipid fraction of different taxa of microalgae affected transferase activity and sex hormone levels in mice.

Microalgae are a resource of bioactive molecules with antioxidant, anti-inflammatory activities [11-14]. Recent studies have reported that Spirulina dietary treatments of the chicken facilitated increased body weight, and Chlorella vulgaris caused increased growth of Nile tilapia (Orechromisniloticus niloticus) [5, 15]. Moreover, Chlorela vulgaris, Nannochloropsis oceanica, and Phaeodactylum Tricornutum intake by mice during 14 days had no toxic effect [6]. Previous studies have shown that Chlorella vulgaris in mice restored granulocytemacrophage colony-forming binding ability in tumor-bearing mice, and mice exposed to stress Chlorela vulgaris treatment prevented myelosuppression [16, 17]. Porphyridium cruentum in Litopenaeus vannamei shrimp increased the number of hemocytes, phagocytosis and reactive oxygen species production [18]. Spirulina platensis in patients with HIV-1 has the ability to increase the number of CD4 cells after treatment [19]. Recent studies have reported that Parachlorella kessleri HY1 (Chlorellaceae) heterotrophic mutant green algae activated T- and B-cells [20]. Exopolysaccharides of Chlorella sp. induced NO, TNFa, and IL-6 production by macrophage RAW264.7, while Chlorella vulgaris treatment in cyclophosphamide-induced immunosuppression in mice increased splenocytes proliferation, NK cytotoxicity, peritoneal macrophage proliferation and phagocytosis, IL-2, IL-12, TNF- $\alpha$ and IFN- $\gamma$ expression in splenocytes, and production by splenocyte IL-2, IL-12, TNF- $\alpha$ and IFN- $\gamma$ [21, 22]. Spirulina platensis oral administration in diabetic rats reduced the level of malondialdehyde, ALT, AST, TNFa, and IL-6 [23]. In rabbits Chlorella vulgaris reduced ALT activity, decreased serum triglycerides, very-low-density lipoproteins, and malondialdehyde [24]. Scenedesmus obliquus intake in mice had no toxic effect on the liver, and in dosage $0.25 \mathrm{mg} / \mathrm{kg}^{-1}$ had no caused changes in total cholesterol, triglycerides, low- and high-density lipoproteins in blood serum [25]. Oral administration in rats of Tisochrysis lutea did not affect ALT, while TC, LDL-C increased and had no effect on HDL-C, and TG levels [26]. Recent studies have shown that the microalgae diet in pigs from the 75th day of pregnancy had not caused changes in cortisol levels [27]. Green microalgae Dunaliella salina administration in Boer goats for 11 days 
increased in number and size of ovarian follicles and corpus lutea, progesterone, estrogen, follicle-stimulating hormone, and luteinizing hormone higher during the estrous cycle, while it decreased total protein, albumin, AST and ALT in blood serum [28].

\section{Conclusions}

Therefore, these studies confirm our current findings that lipid fraction of different taxa of microalgae might influence immunocyte quantity and quality and have no significant adverse effect on mice.

\section{Funding}

This research was carried out within the framework of government research assignment of RICEL-branch of ICG RAS "Development of methods of molecular profiling and innovative technologies for prediction, early diagnosis, drug and cell therapy of socially significant human diseases of autoimmune, inflammatory and dysmetabolic nature" No. AAAA-A19119031590016-0 and IBSS RAS "Investigation of the mechanisms of controlling production processes in biotechnological complexes with the aim of developing the scientific foundations for the production of biologically active substances and technical products of marine genesis" No. AAAA-A18-118021350003-6.

\section{Acknowledgments}

The authors declare no acknowledgments.

\section{Conflicts of Interest}

The authors have no conflict of interest to declare.

\section{References}

1. Abdel-Aziem, S.H.; Abd El-Kader, H.A.M.; Ibrahim, F.M.; Sharaf, H.A.; El Makawy, A.I. Evaluation of the alleviative role of Chlorella vulgaris and Spirulina platensis extract against ovarian dysfunctions induced by monosodium glutamate in mice. J Genet Eng Biotechnol. 2018, 16, 653-660, https://doi.org/10.1016/j.jgeb.2018.05.001.

2. Tabarzad, M.; Atabaki, V.; Hosseinabadi, T. Anti-inflammatory activity of bioactive compounds from microalgae and cyanobacteria by focusing on the mechanisms of action. Mol Biol Rep. 2020, 47, 6193-6205, https://doi.org/10.1007/s11033-020-05562-9.

3. De Morais, M.G.; Vaz, B.S.; de Morais, E.G.; Costa, J.A.V. Biologically active metabolites synthesized by microalgae. BioMed Res Int. 2015, 4, 1-16, https://doi.org/10.1155/2015/835761.

4. Lykov, A.; Rachkovskaya, L.; Surovtseva, M.; Kim, I.; Korolev, M.; Kotlyarova, A.; Letyagin, A.; Poveshchenko, O.; Gevorgiz, R.; Zheleznova, S. In vitro and in vivo effect of the composition of fucoxanthin with porous aluminum-silicon career on cells. Biointerface Res App Chem. 2021, 11, 9467-9476, https://doi.org/10.33263/BRIAC112.94679476.

5. Khan, S.; Mobashar, M.; Mahsood, F.K; Javaid, S.; Abdel-Wareth, A.A; Ammanullah, H.; Mahmood, A. Spirulina inclusion levels in a broiler ration: evaluation of growth performance, gut integrity, and immunity. Trop Anim Health Prod. 2020, 52, 233-3240, https://doi.org/10.1007/s11250-020-02349-9.

6. Neumann, U.; Derwenskus, F.; Gille, A.; Louis, S.; Schmid-Staiger, U.; Briviba, K.; Bischoff, S.C. Bioavailability and safety of nutrients from the microalgae Chlorella vulgaris, Nanochloropsis oceanica and Phaeodactylum tricornutum in C57BL/6 mice. Nutrients. 2018, 10, 965, https://doi.org/10.3390/nu10080965.

7. Patwal, T.; Baranwal, M. Scenedesmus acutus extracellular polysaccharides produced under increased concentration of sulphur and phosphorus exhibited enhanced proliferation of peripheral blood mononuclear cells. 3 Biotech. 2021, 11, 171, https://doi.org/10.1007/s13205-021-02720-z. 
8. Choo, W.T.; Teoh, M.L.; Phang, S.M.; Convey, P.; Yap, W.H.; Goh, B.H.; Beardall, J. Microalgae as potential anti-inflammatory natural product against human inflammatory skin diseases. Front Pharmacol. 2020, 11, 1086, https://doi.org/10.3389/fphar.2020.01086.

9. El-Baz, F.K.; Saleh, D.O.; Abdel Jaleel, G.A.; Hussein, R.A. Attenuation of age-related hepatic steatosis by Dunaliella salina microalgae in senescence rats through the regulation of redox status, inflammatory indices, and apoptotic biomarkers. Adv Pharmacol Pharm Sci. 2020, https://doi.org/10.1155/2020/3797218.

10. Lee, A.H.; Shin, H.Y.; Park, J.H.; Koo, S.Y.; Kim, S.M.; Yang, S.H. Fucoxanthin from microalgae Phaeodactylum tricornutum inhibits proinflammatory cytokines by regulating both NF-kB and NLRP3 inflammasome activation. Sci Rep. 2021, 11, 543, https://doi.org/10.1038/s41598-020-80748-6.

11. Yi, R.; Deng, L.; Mu, J.; Li, C.; Tan, F.; Zhao, X. The impact of antarctic ice microalgae polysaccharides on d-galactose-induced oxidative damage in mice. Front Nutr. 2021, https://doi.org/10.3389/fnut.2021.651088.

12. Bhattacharyya, S.; Mehta, P. The hepatoprotective potential of Spirulina and vitamin C supplemention in cisplatin toxicity. Food Funct. 2012, 3, 164-169, https://doi.org/10.1039/c1fo10172b.

13. Murthy, K.N.; Rajesha, J.; Swamy, M.M.; Ravishankar, G.A. Comparative evaluation of hepatoprotective activity of carotenoids of microalgae. J Med Food. 2005, 8, 523-528, https://doi.org/10.1089/jmf.2005.8.523.

14. Li, W.; Luo, C.; Huang, Y.; Zhan, J.; Lei, J.; Li, N.; Huang, X.; Luo, H. Evaluation of antifatigue and antioxidant activities of the marine microalgae Isochrysisgalbana in mice. Food Sci Biotechnol. 2019, 29, 49-557, https://doi.org/10.1007/s10068-019-00694-6.

15. Mahmoud, E.A.; El-Sayed, B.M.; Mahsoub, Y.H.; El-Murr, A.E.I.; Neamat-Allah, A.N.F. Effect of Chlorella vulgaris enriched diet on growth performance, hemato-immunological responses, antioxidant and transcriptomics profile disorders caused by deltamethrin toxicity in Nile tilapia (Oreochromis niloticus). Fish Shellfish Immunol. 2020, 102, 422-429, https://doi.org/10.1016/j.fsi.2020.04.061.

16. Ramos, A.L.; Torello, C.O.; Queiroz, M.L. Chlorella vulgaris modulates immunomyelopoietic activity and enhances the resistance of tumor-bearing mice. Nutr Cancer. 2010, 62, 1170-1180, https://doi.org/10.1080/01635581.2010.513801.

17. Souza Queiroz, J.; Barbosa, C.M.V.; da Rocha, M.C.; Bincoletto, C.; Paredes-Gamero, E.J.; de Souza Queiroz, M.L.; Palermo Neto, J. Chlorella vulgaris treatment ameliorates the suppressive effects of single and repeated stressors on hematopoiesis. Brain Behav Immun. 2013, 29, 39-50, https://doi.org/10.1016/j.bbi.2012.12.001.

18. Risjani, Y.; Mutmainnah, N.; Manurung, P.; Wulan, S.N.; Yunianta. Exopolysaccharide from Porphyridium cruentum (purpureum) is not toxic and stimulates immune response against vibriosis: the assessment using zebrafish and white shrimp Litopenaeus vannamei. Mar Drugs. 2021, 19, 133, https://doi.org/10.3390/md19030133.

19. Ngo-Matip, M.E.; Pieme, C.A.; Azabji-Kenfack, M.; Moukette, B.M.; Korosky, E.; Stefanini, P.; Ngogang, J.Y.; Mbofung, C.M. Impact of daily supplementation of Spirulina platensis on the immune system of naïve HIV-1 patients in Cameroon: a 12-months single blind, randomized, multicenter trial. Nutr J. 2015, 14, 70, https://doi.org/10.1186/s12937-015-0058-4.

20. Sushytskyi, L.; Lukáč, P.; Synytsya, A.; Bleha, R.; Rajsiglová, L.; Capek, P.; Pohl, R.; Vannucci, L.; Čopíková, J.; Kaštánek, P. Immunoactiv epolysaccharides produced by heterotrophic mutant of green microalga Parachlorella kessleri HY1 (Chlorellaceae). Carbohydr Polym. 2020, https://doi.org/10.1016/j.carbpol.2020.116588.

21. Wu, S.; Liu, H.; Li, S.; Sun, H.; He, X.; Huang, Y.; Long, H. Transcriptome analysis reveals possible immunomodulatory activity mechanism of Chlorella sp. exopolysaccharides on RAW264.7 macrophages. Mar Drugs. 2021, 19, 217, https://doi.org/10.3390/md19040217.

22. Cheng, D.; Wan, Z.; Zhang X.; Li, J.; Li, H.; Wang, C. Dietary Chlorella vulgaris ameliorates altered immunomodulatory functions in cyclophosphamide-induced immunosuppressive mice. Nutrients. 2017, 9 , 708, https://doi.org/10.3390/nu9070708.

23. Nasirian, F.; Dadkhah, M.; Moradi-Kor, N.; Obeidavi, Z. Effects of Spirulina platensis microalgae on antioxidant and anti-inflammatory factors in diabetic rats. Diabetes Metab Syndr Obes. 2018, 11, 375-380, https://doi.org/10.2147/DMSO.S172104.

24. Abdelnour, S.A.; Sheiha, A.M.; Taha, A.E.; Swelum, A.A.; Alarifi, S.; Alkahtani, S.; Ali, D.; AlBasher, G.; Almeer, R.; Falodah, F.; Almutairi, B.; Abdel-Daim, M.M.; Abd El-Hack, M.E.; Ismail, I.E. Impacts of enriching growing rabbit diets with Chlorella vulgaris microalgae on growth, blood variables, carcass traits, immunological and antioxidant indices. Animals (Basel) 2019, 9, 788, https://doi.org/10.3390/ani9100788.

25. do Nascimento, T.C.; Cazarin, C.B.B.; Maróstica, M.R. Jr.; Mercadante, A.Z.; Jacob-Lopes, E.; Zepka, L.Q. Microalgae carotenoids intake: Influence on cholesterol levels, lipid peroxidation and antioxidant enzymes. Food Res Int. 2020, https://doi.org/10.1016/j.foodres.2019.108770.

26. Mayer, C.; Richard, L.; Côme, M.; Ulmann, L.; Nazih, H.; Chénais, B.; Ouguerram, K.; Mimouni, V. The marine microalga, Tisochrysis lutea, protects against metabolic disorders associated with metabolic syndrome and obesity. Nutrients. 2021, 13, 430, https://doi.org/10.3390/nu13020430. 
27. You, L.; Lee, A.V.; Oh, S.Y.; Fisher-Heffernan, R.E.; Edwards, M.; de Lange, K.; Karrow, N.A. Effect of lipopolysaccharide-induced immune stimulation and maternal fish oil and microalgae supplementation during late pregnancy on nursery pig hypothalamic-pituitary-adrenal function. J Anim Sci. 2019, 97, 2940-2951, https://doi.org/10.1093/jas/skz166.

28. Senosy, W.; Kassab, A.Y.; Mohammed, A.A. Effects of feeding green microalgae on ovarian activity, reproductive hormones and metabolic parameters of Boer goats in arid subtropics. Theriogenology. 2017, 96, 16-22, https://doi.org/10.1016/j.theriogenology.2017.03.019. 